\title{
As Dinâmicas Informacionais do conteúdo publicado pelos Governos do Ceará, do Maranhão e de Pernambuco e as relações com as estatísticas por coronavírus
}

Denise Braga Sampaio

Mestra em Ciência da Informação pela Universidade Federal de Pernambuco (UFPE). Professora da Universidade Federal da Bahia (UFBA).

denisebs23@gmail.com

Maria Cleide Rodrigues Bernardino

Doutora em Ciência da Informação pela Universidade de Brasília (UnB). Professora do Programa de PósGraduação em Biblioteconomia da Universidade Federal do Cariri (UFCA).

cleide.rodrigues@ufca.edu.br

Marcela Lino da Silva

Mestra em Ciência da Informação pela Universidade Federal de Pernambuco (UFPE).

linomarcela@gmail.com

Phelipe Rafael Alves de Menezes

Pós-graduando em Desenvolvimento, Inovação e Tecnologias Emergentes, pelo IFPE.

menezesphelipe@gmail.com

\section{Resumo}

Buscou-se identificar a dinâmica informacional dos perfis oficiais de governos dos estados do Nordeste do Brasil - Ceará, Maranhão e Pernambuco - quanto à disseminação de informações durante a pandemia mundial da Covid-19. Para tanto, foi realizada uma categorização das informações veiculadas para refletir quanto ao volume das informações e avaliar as dinâmicas dos conteúdos e suas relações com os dados estatísticos de infectados e mortos nesses estados. Metodologicamente, realizou-se uma categorização das publicações do Instagram oficial de cada governo e usou-se a Análise de Redes Sociais (ARS), que possui uma abordagem quali-quantitativa, para mapear as interações e a análise de padrões de relacionamento e fluxo informacional com os dados coletados. Isso permitiu compreender a comunicação no contexto das organizações a partir do viés relacional e processual. A partir disso, concluiu-se que a maioria das publicações é de conteúdo relacionado a medidas de enfrentamento à Covid-19, o que denota uma preocupação dos governos dos estados em demonstrar à população suas ações formais para minimizar os impactos causados pelo novo coronavírus. Além disso, o resultado ratificou Pernambuco como o estado mais transparente em relação à divulgação de dados e informações acerca dos casos da doença no estado.

Palavras-chave: Covid-19. Novo coronavírus. Nordeste do Brasil. Redes Sociais. Dinâmicas informacionais.

The Informational Dynamics of Content Published by the Governments of Ceará, Maranhão and Pernambuco and the Relationship with Statistics for Coronavirus

\section{Abstract}

This article sought to identify the information dynamics of the official profiles of the governments of states from Brazil's northeast region - Ceará, Maranhão and Pernambuco - regarding the dissemination of information during the Covid-19 world pandemic. Therefore, a categorization of the information conveyed was carried out to reflect about the volume of information and to assess the dynamics of its contents and their relationship with the statistical data of infected people and deaths rates in those states. Methodologically, a categorization of the official Instagram publications from each government was carried out, followed by a social network analysis, which has a qualitative and quantitative approach, to map interactions and the analysis of relationship patterns and information flow within the data collected. This allowed us to understand the communication in the context of organizations from a relational and procedural perspective. From this, it was concluded that most of the publications have content related to measures to combat Covid-19, which denotes a concern of states' governments to demonstrate to the population their formal actions to minimize the impacts caused by the new coronavirus. In addition, the result ratified Pernambuco as the most transparent state in relation to the dissemination of data and information about the cases of the disease in the state.

Keywords: Covid-19. New coronavirus. Northeast of Brazil. Social networks. Informational dynamics. 


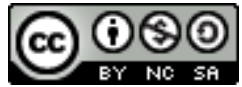 \\ Este trabalho está licenciado com uma Licença Creative Commons - Atribuição- NãoComercial-Compartilhalgual 4.0 \\ Internacional.}

\section{Introdução}

O processo informacional da sociedade em rede em tempos de pandemia global, como a de 2020, segue uma dinâmica característica das sociedades fluídas e urgentes. Claro que, para entender a sociedade em rede, é preciso compreender a sociedade na era industrial, conforme aponta Schaff (1995). Para o referido autor, na sociedade industrial a ação do homem incide diretamente sobre, dando-se a partir de espaços bem delimitados e em uma concordância tanto temporal como física, já na sociedade em rede ou como prefere chamar, sociedade da informação, as barreiras espaciais, temporais e físicas são rompidas. Com isto, ocorre um processo social interacional mediado pelas tecnologias, pela informação e pelo conhecimento. Como assim e informação e conhecimento não é tudo a mesma coisa ou estão totalmente ligados? Calma, as respostas não são tão simples. Burke (2003, p. 19), ao tentar responder o que era conhecimento, afirma que chega a ser tão difícil quanto responder o que é verdade. Dessa forma, o autor metaforiza e diz que informação é aquilo que é "cru, específico e prático" e que conhecimento, aquilo que foi "cozido, processado ou sistematizado pelo pensamento". Claro que não se busca aqui responder a nenhuma dessas questões. Nosso papel é muito mais problematizador que qualquer outro. Porém, tomando de empréstimo as concepções de sociedade em rede e o que se entende por informação e conhecimento, buscar-se-a responder o seguinte questionamento: qual a dinâmica informacional dos estados do Nordeste do Brasil quanto à disseminação de informações durante a pandemia mundial do Covid-19 através de redes sociais digitais?

A transição da sociedade industrial para a sociedade da informação trouxe mudanças na economia, na política, nas relações de trabalho e, claro, nas relações sociais. Em contraponto à visão cética de Schaff (1995) quanto aos benefícios das Tecnologias da Informação e da Comunicação (TIC) no contexto econômico, político, cultural e social, Alvim Toffler (1990), em seu livro 'Powerhift', apresenta uma visão otimista sobre a tecnologia, associando-a como meio de comunicação e de produção de riquezas. Errado não estava, entretanto, em sistemas capitalistas, as riquezas são concentradas em poucos, ou seja, aquilo que gera riquezas para uns, gera também a miséria para outros. O que faz com que se concorde também com Schaff (1995) ao apontar as consequências sociais da sociedade da informação. As desigualdades sociais interferem diretamente nos meios de produção e consumo de informação. O próprio Toffler (1990, p. 384) afirma ser possível reconhecer as profundas tensões sociais provocadas pela introdução das TIC na economia, causando uma "divisão da população em inforrica e infopobre".

Em obra anterior, 'A Terceira Onda', Toffler (1980) já falava das transformações da sociedade sob o impacto das TIC que alterariam as formas e modos de trabalho e produção e em que a informação é a grande protagonista. Sobre isto, Toffler (1980, p. 275) afirma que "Muitos dos mesmos dispositivos eletrônicos que usaremos em casa para fazer trabalho remunerado também tornarão possível produzir mercadorias ou serviços para nosso próprio uso".

Essa transformação trouxe consigo uma espécie de síndrome da pressa. O fluxo informacional nesta sociedade é rápido e dinâmico. Não se pode afirmar que isto é um fenômeno dos tempos modernos. Não, Gitlin (2003) já afirmava que a sociedade nunca foi estática. As invenções ao longo da história sempre buscaram encurtar os caminhos e processos e facilitar a vida da sociedade.

As invenções se disseminam mais rápido do que há um século, afetando mais pessoas mais depressa. Líderes religiosos e profetas, reis e outros governantes buscavam novas conquistas, novas terras, novos conhecimentos, novas experiências. A insatisfação era, muitas vezes, o motor da inovação moral, filosófica, política e técnica. A agitação intelectual não era rara. Ainda assim, o ritmo da mudança e da inovação social era, pelo padrão moderno, lento (GITLIN, 2003, p. 112). 
Com a rapidez vem a banalidade das coisas, das informações. Não há tempo de demorar-se com o que Burke (2003) chama de processar a informação e gerar conhecimento. Essa velocidade da informação foi pontuada por Ortega y Gasset na obra 'A Rebelião das Massas', de 1987, em que refletiu sobre a preponderância das tecnologias no final do Século XX e a necessidade do homem em vencer o espaço e o tempo, uma espécie de culto à velocidade: "[...] não há por que se estranhar o prazer pueril que nos dá fazer funcionar a velocidade, com o qual matamos espaço e estrangulamos o tempo" (ORTEGA Y GASSET, 1987 apud SÊGA, 2011, p. 118).

O paradoxo da sociedade fluída é que a mesma tecnologia que aproxima distâncias produz distanciamentos. Na modernidade, conforme conclui Bauman (2001, p. 16), "A própria ideia de velocidade (e mais ainda a de aceleração), quando se refere à relação entre tempo e espaço, supõe sua variabilidade, e dificilmente teria qualquer significado se não fosse aquela uma relação verdadeiramente variável [...]". Ao mesmo tempo em que se tem uma necessidade de informação o mais rápido possível, essa mesma informação rapidamente perde a relevância com a chegada de uma nova informação. E nenhuma delas, precisa ser totalmente processada e assimilada como conhecimento.

As dinâmicas informacionais amparam-se no paradigma contemporâneo comunicacional que é alicerçado pelo conceito de informacionalismo de Castells (2009 apud SANTOS, 2014, p. 35-36 grifo nosso) que corresponde a "[...] um novo modelo de desenvolvimento nascido da emergência de um paradigma tecnológico novo, fundado na tecnologia da informação" que por sua vez caracterizam os modelos comunicacionais em rede - caracterizado por novos e abrangentes processos e contextos de comunicação".

Partindo dessa ideia e da problemática levantada, pretende-se, com este artigo, identificar a dinâmica informacional dos perfis oficiais de governos dos estados do Nordeste do Brasil - Ceará, Maranhão e Pernambuco - quanto à disseminação de informações durante a pandemia mundial de Covid-19. Especificamente, pretende-se realizar uma categorização das informações veiculadas, refletir quanto ao volume das informações e avaliar as dinâmicas dos conteúdos veiculados em paralelo com os dados estatísticos de infectados e mortos nesses estados, ou seja, em suma, identificar a consistência e performance informacional em rede social, no caso o Instagram.

Metodologicamente, usou-se a análise de redes sociais (ARS) que permite compreender a comunicação no contexto das organizações a partir do viés relacional e processual. A ARS é uma metodologia de abordagem quali-quantitativa que possibilita o mapeamento da interação e a análise dos padrões de relacionamento e do fluxo informacional (MARTELETO, 2010).

\section{Coronavírus, a pandemia do mundo globalizado}

A globalização é consequência da intensificação das relações econômicas, sociais, culturais e políticas entre os países do mundo e esse processo tem início com os intercâmbios, cada vez mais frequentes, originados desde o período mercantilista, do século XV ao XVIII, com as expansões marítimas europeias, que buscavam riqueza por meio das exportações e exploração de territórios, consolidando assim um pensamento econômico cada vez mais focado no lucro, desenvolvimento das indústrias e competição comercial. Com o avanço das tecnologias, a partir do século XIX e, mais ainda, com a revolução informacional no século XX, os movimentos da globalização, pós-Segunda Guerra Mundial, intensificaram-se e a conexão entre os países se tornou cada vez maior, sobretudo com o advento da Internet. Os meios de transporte facilitaram as viagens e os meios de comunicação permitiram a aproximação das pessoas mesmo distantes geograficamente. Essas transformações configuraram o mundo em uma 'aldeia global' (MCLUHAN, 1962), com fluxo rápido de informação e pessoas entre os continentes do mundo.

Embora o desenvolvimento das tecnologias tenha permitido a facilidade de comunicação e deslocamento entre as nações, por meio de perspectivas econômicas e políticas, a globalização também traz com ela características relacionadas ao conceito de cultura, uma globalização cultural. Esse conceito envolve aspectos relativos à fusão de tradições, comportamentos e elementos típicos de uma cultura em detrimento de outra, o que, muitas vezes, equivale à supremacia hegemônica de algumas culturas, sobretudo eurocêntricas, sobre culturas regionais e locais. Quando McLuhan (1962) traz o conceito de aldeia global, ele centra a discussão nos padrões socioculturais resultantes dos meios comunicacionais que modelam o modo como as pessoas vivem no mundo. Entretanto, esse pensamento é criticado por Milton Santos (2001), que pontua que nesse conceito 
o indivíduo só está inserido nesse processo se possuir os recursos tecnológicos para que isso aconteça, ou seja, a aldeia global não é para todos, mas sim para quem tem os meios de fazer parte dela.

Nessa perspectiva, o encurtamento de distâncias e o progresso tecnológico ocorreriam apenas para um grupo hegemônico e este interligaria a sociedade, impondo as transformações socioculturais, econômicas e políticas. Desse modo, Milton Santos (2001) afirma que "[...] a globalização é, de certa forma, o ápice do processo de internacionalização do mundo capitalista. Para entendê-la, como, de resto, a qualquer fase da história, há dois elementos fundamentais a levar em conta: o estado das técnicas e o estado da política" (SANTOS, 2001, p. 23).

\begin{abstract}
A história do capitalismo pode ser dividida em períodos, pedaços de tempo marcados por certa coerência entre as suas variáveis significativas, que evoluem diferentemente, mas dentro de um sistema. Um período sucede a outro, mas não podemos esquecer que os períodos são, também, antecedidos e sucedidos por crises, isto é, momentos em que a ordem estabelecida entre as variáveis, mediante uma organização, é comprometida. Torna-se impossível harmonizá-las quando uma dessas variáveis ganha expressão maior e introduz um princípio de desordem (SANTOS, 2001, p. 33).
\end{abstract}

Santos (2001) salienta ainda que o processo da crise é permanente e que crises são sucessivas, seja por meio de fenômenos globais como de manifestações particulares em um determinado país. Para ele, a crise é estrutural e quando se buscam soluções não estruturais, o resultado é a geração de mais crise (SANTOS, 2001). Essa inferência remete a crises políticas e econômicas, que reverberam em vários países, e, em um contexto recente, a crises sanitárias, a exemplo da pandemia do novo coronavírus (Covid-19), que em um curto período atingiu o mundo. Depreende-se, portanto, que as ações para a conter devem ser estruturais ou, do contrário, a perversidade inerente à violência da informação (informação manipulada e ideológica) e à violência do dinheiro (relações econômicas que favorecem grandes empresas financeiras) sustentarão o sistema ideológico mantenedor de grandes crises.

Entre os fatores constitutivos da globalização, em seu caráter perverso atual, encontram-se a forma como a
informação é oferecida à humanidade e a emergência do dinheiro em estado puro como motor da vida
econômica e social. São duas violências centrais, alicerces do sistema ideológico que justifica as ações
hegemônicas e leva ao império das fabulações, a percepções fragmentadas e ao discurso único do mundo,
base dos novos totalitarismos - isto é, dos globalitarismos - a que estamos assistindo (SANTOS, 2001, p. 38).

O contexto da atual pandemia da Covid-19 revela características da globalização e seus impactos sobre as economias. Quando surgiu em dezembro de 2019 na cidade de Wuhan, na China, não se imaginava o quanto a disseminação deixaria vulnerável uma das maiores potências mundiais, os Estados Unidos, que se encontra em primeiro lugar entre os países mais afetados do mundo, em números de infectados e mortos.

Tostes e Melo Filho (2020) trazem à tona a discussão em torno dos comportamentos e estruturas culturais que podem ser transformadas e/ou reivindicadas, nos âmbitos do modo de produção capitalista, criação de políticas públicas, legitimação dos direitos, acesso à educação e à saúde, convergindo esses vieses para a redução da desigualdade social, que reverbera, considerando o contexto da pandemia, em um maior impacto sobre o desenvolvimento das populações. Acerca dessas configurações territoriais e a influência do espaço produzido pela ação humana, em uma dinâmica particular de condições socioeconômicas, políticas, institucionais, entre outras, Miranda, Barcellos, Moreira e Monken (2008) alertam para preocupações na área da saúde pública. Os autores salientam que cada configuração espacial comporta um tipo de população que, a depender da localização no território, vai estar mais ou menos exposta a riscos, como as doenças, a violência e a falta de qualidade de vida, advinda da falta de saneamento, renda, habitação e lazer. Esses fatores, somados ao território, reforçam a possibilidade de adoecimento e morte da população, uma vez que esses grupos estão mais vulneráveis à doença e à falta de assistência para se prevenir e/ou tratá-la.

Boaventura de Sousa Santos (2020), em 'A Cruel Pedagogia do Vírus', afirma que o sentido literal da pandemia é o medo generalizado da morte que não tem fronteiras e que traz um inimigo invisível. O fato é que a palavra pandemia já assusta de imediato, ainda mais uma que, até 23 de junho de 2020, já matou mais de 476 mil pessoas no mundo e mais de 52 mil pessoas no Brasil1. Essa situação imprime na sociedade uma nova dinâmica das relações, sejam elas econômicas, políticas,

\footnotetext{
${ }^{1}$ Conforme consórcio de veículos de imprensa. Disponível em: https://news.google.com/covid19/map?hl=pt-
} BR\&mid=/m/01c8c6\&gl=BR\&ceid=BR:pt-419. Acesso em: 24 jun. 2020. 
pedagócias ou sociais. Santos (2020) conclui que o mundo está em crise, que essa crise conduzirá ao que o autor denomina de "normalidade da exceção", em que explica que,

\begin{abstract}
Desde a década de 1980 - à medida que o neoliberalismo se foi impondo como a versão dominante do capitalismo e este se foi sujeitando mais e mais à lógica do sector financeiro-, o mundo tem vivido em permanente estado de crise. Uma situação duplamente anómala. Por um lado, a ideia de crise permanente é um oximoro, já que, no sentido etimológico, a crise é, por natureza, excepcional e passageira, e constitui a oportunidade para ser superada e dar origem a um melhor estado de coisas. Por outro lado, quando a crise é passageira, ela deve ser explicada pelos factores que a provocam. Mas quando se torna permanente, a crise transforma-se na causa que explica tudo o resto (SANTOS, 2020, p. 5, grifo nosso).
\end{abstract}

Ou seja, a crise financeira, por exemplo, tem suas origens nas políticas de recessão adotadas pelos governos capitalistas que extingue políticas sociais, cortam verbas essenciais para a saúde e educação, congela salários e condena seu povo a viver em condições paupérrimas ou miseráveis. Santos $(2020$, p. 6) denuncia ainda que o objetivo de uma crise permanente não é, de forma alguma, a sua resolução, mas "[...] legitimar a escandalosa concentração de riqueza e boicotar medidas eficazes para impedir a iminente catástrofe ecológica". O estilo de vida capitalista, que impõe e incentiva o consumo, tem um impacto muito forte no meio ambiente. Este impacto causa uma desarmonização do planeta, que traz consequências das mais variadas formas, como fenômenos geológicos, a exemplo de tsunamis, ou doenças infecciosas e epidemiológicas.

Outro problema a ser considerado na sociedade capitalista, e que agrava a propagação de vírus como o SARS-CoV-2, é o deslocamento populacional. Ujvari (2011) afirma que a velocidade dos deslocamentos populacionais deve ser levada em consideração para o desenvolvimento de medidas de controle às epidemias, antes que se tornem pandemias e se agrave as probabilidades de transmissão. Matos (2018), ao indagar sobre se estamos preparados para uma próxima pandemia, referindo-se ao marco da pandemia de 1918, afirma que é preciso analisar e prevê situações, que a previsibilidade de uma nova pandemia se assemelhava à previsão do tempo, sendo esta uma consequência de sistemas caóticos. De fato, sua previsão estava correta.

Sobre o Sistema capitalista, Souza (2020, p. 12) afirma que "a dependência do trabalho, a propriedade dos meios de produção e o lucro caracterizam o modo de produção capitalista. Este modo de produção se aliena como ideologia e o sentido do trabalho humano é invertido completamente". Essa dependência do trabalho, por exemplo, aliada à necessidade de consumo desenfreada pode conduzir a população a atitudes insanas que colocam suas vidas e a dos demais em risco constante. Este mesmo Sistema, que engana ao afirmar que diante do Coronavírus somos todos igualmente suscetíveis, nos mostra efetivamente ser uma inverdade, uma vez que a população mais pobre é a mais exposta à contaminação e à transmissão, menos assistida pela saúde do Estado/Nação e mais incentivada à sair do isolamento em nome da economia.

As medidas profiláticas, em se tratando de pandemias, incluem o isolamento dos doentes e pessoas com potencial condições de transmissão ou acometimento. A palavra quarentena, conforme o Dicionário de Termos Médicos (COSTA, [200-] apud SANTOS; NASCIMENTO, 2014, p. 175) é "um período de isolamento imposto a pessoas portadoras ou supostas portadoras de doenças contagiosas". A palavra quarentena etimologicamente tem sua origem no Latim quadraginata e no italiano quaranta e era atribuída inicialmente ao "[...] período de quarenta dias de isolamento de passageiros e cargas em navios, imposto por autoridades de um porto caso suspeitassem que houvesse portadores de infecção entre os passageiros ou tripulantes, obrigados à incomunicabilidade a bordo [...]" (BARBERA et al 2001 apud SANTOS; NASCIMENTO, 2014, p. 175). Atualmente, com as recomendações da OMS a respeito do Novo Coronavírus, termos como quarentena e isolamento social fazem parte do discurso diário das pessoas e meio de comunicação. Enquanto a quarentena se constitui como uma medida profilática imposta pelas Autarquias, seja federal, estadual ou municipal, com o objetivo de diminuir o trândito de pessoas e consequentemente a propagação da doença. Uma forma mais rígida de quarentena, o lockdown, utiliza as forças do Estado para garantir que se cumpra a determinação de isolamento e distanciamento. Já o isolamento é uma recomendação médica de manter as pessoas infectadas, que tiveram contato com pessoas infectadas ou que apresentam sintomas e aguardam resultados de exames, de se manterem isoladas das demais pessoas. Há dois tipos de isolamento: o vertical e o horizontal. $\mathrm{O}$ isolamento vertical é realizado apenas com as pessoas que se encontram nos grupos de risco da doença e o isolamento horizontal, inclui todas as pessoas em distanciamento social².

\footnotetext{
${ }^{2}$ Revista Galileu de 7 de maio de 2020. Disponível em: https://revistagalileu.globo.com/Ciencia/Saude/noticia/2020/05/qual-e-diferenca-
} entre-distanciamento-isolamento-quarentena-e-lockdown.html. Acesso em: 11 maio 2020. 
O isolamento pode se dar no meio hospitalar ou domiciliar. No caso da Covid-19, acontece das duas formas, sendo a primeira para tratar os infectados garantindo que o mínimo de contaminação se dê a partir desses, e o Segundo, como meio preventivo de inibir o contágio da doença. Para que os estados e munícipios possam enfrentar a pandemia, foi necessária a instituição de decretos e resoluções específicas, orientando a respeito da medida a ser tomada. Os que apresentam estatísticas mais críticas quanto ao contágio e óbitos, optaram pelo lockdown $n^{3}$ como meio de garantir o maximo rigor da prevenção e dirimir os efeitos da propagação, tendo em vista a grande transmissibilidade, gravidade clínica e letalidade da Covid-19.

O enfrentamento de pandemias não é algo novo. Há pouco mais de 100 anos, a história registrou a maior pandemia por influenza já vista, conhecida como a 'mãe de todas as pandemias'. A popularmente conhecida 'Gripe Espanhola' de 1918, que apesar de ter esse nome não teve sua origem na Espanha e sim, no estado norte-americano do Kansas e que matou em todo o mundo entre 20 e 50 milhões, segundo os pesquisadores e seus registros (MATOS, 2018). Recentemente, em 2009, o vírus Influenza A (H1N1), causador da pandemia de 1918, voltou a fazer vítimas e convive conosco até os dias atuais, porém sem grande letalidade devido ao desenvolvimento de vacinas e anticorpos (UJVARI, 2011).

Ainda em alusão à catástrofe ecológica (SANTOS, 2020), aponta-se a extensão das devastações ambientais que o capitalismo vem causando ao planeta, ao longo dos séculos, ocasionando diversos males e pandemias, como é o caso da peste bulbônica, a AIDS, o Ebola, a Malária etc., e, claro a Covid-19. "A diferença entre a pandemia atual e as que as antecederam é velocidade de contágio e a consequente letalidade da Covid-19. O período médio de incubação do vírus dura de 5 a 6 dias e a transmissão geralmente se inicia de 24 a 48 horas após o aparecimento dos primeiros sintomas" (REIS JÚNIOR, 2020, p. 165). Sobre esta rapidez, na transmissão e contágio, associada às políticas do Estado Capitalista, Reis Júnior (2020, p. 167) afirma ainda que,

\begin{abstract}
A Pandemia chega num momento de grande hegemonia da Teoria do Estado Mínimo do neoliberalismo, que nas últimas décadas vem promovendo um violento e acelerado desmonte do Estado de Bem Estar Social (EBES) construído a duras penas pela humanidade, principalmente na Europa e nos EUA no período pós segunda grande guerra mundial e em alguns países da América Latina no começo dos anos 2.000. Não é coincidência que depois da China, o primeiro epicentro da Pandemia, a Itália, a Espanha, a França, os EUA e o Reino Unido se tornam respectivamente os novos epicentros da Pandemia da COVID-19.
\end{abstract}

Mais uma vez, chega-se à questão da previsibilidade de que fala Matos (2018), prevê as condições do planeta e da vida das pessoas delineadas pelas políticas econômicas capitalistas é uma política de combate à novas pandemias. A letalidade de um virus, como o novo Coronavírus, em um país como o Brasil, com alto índice de desigualdade social e contaminado por práticas políticas desviantes e corruptas, é no mínimo previsível. Muito se fala em crise econômica no país, porém, há uma crise ainda maior, de ordem política e social, que afeta não somente à economia, mas à saúde das pessoas.

A conclusão mais evidente da crise causada pela pandemia que devem ser direcionadores de política pública no futuro, é que o Estado Mínimo é um genuíno suicídio. Sem o EBES, não há sistema de saúde ou organização social que impeça que a próxima pandemia chegue para dizimar a sociedade e não há outro agente forte, senão o Estado, para garantir a renda do trabalhador e a sobrevivência das empresas (REIS JÚNIOR, 2020, p. 173).

O mundo globalizado impõe dinâmicas crueis de sobrevivência. Não é possível pensar a saída da crise sem reavaliar as condições do capitalismo no país, sem refletir acerca do desenvolvimento desenfreado e suas consequências ao equilíbrio ambiental, sem avaliar políticas de inclusão e equidade social, sem contruir novas dinâmicas de convívio com a sociedade e o meio ambiente. Encerra-se esta seção com um olhar reflexivo sobre nós de forma individual e coletiva, sobre qual nosso papel enquanto bibliotecários, gestores e cientistas da informação em um mundo globalizado que empurra diariamente à dinâmicas condicionantes e manipuladoras como se estivéssemos no mundo futurista de Huxley ${ }^{4}$ de uma nova organização social incerta e autoritária.

\footnotetext{
${ }^{3}$ Medidas tomadas pelos Estados do Ceará e do Maranhão que integram o corpus investigativo desse artigo.

${ }^{4}$ Alusão à obra de Aldous Huxley, Admiravel Mundo Novo, romance futurista que narra o Estado totalitário vivido no ano de $634 \mathrm{dF}$ (Depois de Ford).
} 


\section{Relação entre transparência e dinâmicas informacionais do Poder Executivo Estadual nas redes sociais digitais}

A informação é um direito humano essencial (SAMPAIO, 2016), dado que está presente no cotidiano das pessoas, na qualidade não somente de subsídio à instrução, mas também como elemento base para a manutenção da vida e, especialmente, da qualidade desta. Segundo a Declaração Universal dos Direitos Humanos (DUDH), em seu Artigo XIX, "todo ser humano tem direito à liberdade de opinião e expressão; este direito inclui a liberdade de, sem interferência, ter opiniões e de procurar, receber e transferir informações e ideias por quaisquer meios e independentemente de fronteiras" (ORGANIZAÇÃO DAS NAÇÕES UNIDAS, 2009, p. 10, grifo nosso).

O grifo acima destaca, no artigo em questão, três ações atinentes à informação: a busca (tratada como procura na DUDH), o acesso (ato de receber e transferir) e, implicitamente, também a produção desta. Ao se lembrar, por exemplo, do que versam os autores (AMERICAN LIBRARY ASSOCIATION, 2000; DUDZIAK, 2003; LAU, 2008) da competência em informação (Coinfo), há, para com a informação, uma dinâmica ligada a este uso, produção e disseminação, levando-se em consideração os aspectos tecnológicos, técnicos, socioculturais, econômicos, políticos, geográficos, históricos etc. É passível de lembrança que a DUDH fora concebida em 1948, após Assembleia Geral e, neste período, os fenômenos ligados à desinformação e pósverdade não impactavam a sociedade, como hoje impactam. O crescimento do uso das redes sociais digitais inaugura não somente uma nova forma de veicular a informação, mas também de como os sujeitos se colocam no mundo, assumindo o papel de prossumidores de informação, o que potencializa não somente o uso, mas a produção de novas informações.

Logo, anterior a estas ações de que fala a DUDH, de procurar, receber e transferir a informação, deve-se problematizar que informações são produzidas, por quem, para que fins, de forma constante, dado que informações imprecisas, incorretas, descontextualizadas ou equivocadas podem gerar opiniões e pontos de vista igualmente equivocados ou, nos casos mais extremos, ações efetivas de nocividade.

Neste sentido, a informação é um pharmakon, que pode tanto 'curar' uma patologia informacional anteriormente constituída, por fatores diversos, como pode comportar-se como uma infotoxina (PHILLIPS, 2002), a partir do seu excesso, da sua incompletude, ou imprecisão ou de fatores outros, acidentais ou propositais, gerando ou fortalecendo tal patologia. Portanto, há sob a informação, uma ambivalência moral/ética que incide potencialmente nos aspectos físicos, mentais, comportamentais. De forma ilustrativa, a informação pode garantir a saúde não somente cognitiva e intelectual, mas física dos sujeitos, por exemplo, ao se informar à população que o uso das máscaras de proteção é importante para diminuir a taxa de contaminação do Covid-19, o ato tem papel potencial de ensejar nas pessoas, o seu efetivo uso. No entanto, informar não garante, necessariamente, que tais práticas serão seguidas, por isso, seu papel é potencial. Há um processo ulterior de consciência, consciência, em primeira instância, da necessidade de informação e, consequentemente, das implicações de seu uso e não uso, de como se dá este uso e os meios de acesso à informação, desafio constante na sociedade dita 'da informação'.

Desta maneira, iniciativas, as mais diversas, são desencadeadas e potencializadas, especialmente com o desenvolvimento das Tecnologias da Informação e Comunicação (TIC) e, hodiernamente, com a inserção das mídias digitais sociais no cotidiano de uma parcela significativa (porém, ainda não totalizante) da população mundial. A partir desta concepção de informação como direito, mais precisamente, do acesso à informação, o governo federal, no ano de 2011, na gestão da então presidenta Dilma Rousseff, regula a Lei no 12.527 (Lei de Acesso à Informação) que tem por diretrizes a/o (BRASIL, 2011, grifo nosso):

\section{I - observância da publicidade como preceito geral e do sigilo como exceção;}

II - divulgação de informações de interesse público, independentemente de solicitações;

III - utilização de meios de comunicação viabilizados pela tecnologia da informação;

IV - fomento ao desenvolvimento da cultura de transparência na administração pública;

V - desenvolvimento do controle social da administração pública. 
Estas diretrizes são consoantes com o que preconiza a Constituição Federal em seu inciso XXXIII do art. 5o, uma vez que: "Todos têm direito a receber dos órgãos públicos informações de seu interesse particular, ou de interesse coletivo ou geral, que serão prestadas no prazo da lei, sob pena de responsabilidade, ressalvadas aquelas cujo sigilo seja imprescindível à segurança da sociedade e do Estado" (BRASIL, 1988). Este inciso, bem como o inciso Il do $\S 3^{\circ}$ do art. 37 e o $\S 2^{\circ}$ do art. 216 (BRASIL, 1988) serviram de base à redação da Lei 12.527/2011, mostrando o alinhamento da gestão pública brasileira com a transparência (NOBRE; PORTO, 2012).

É pensando nesta transparência que os governos estaduais e municipais, no contexto do Coronavírus, apresentam à população balanços diários referentes às taxas de contágio/infecção, óbito e recuperação das pessoas acometidas pela enfermidade, bem como os gastos e ações concernentes a estes, na tentativa de dar uma resposta em relação à realidade da pandemia e o que se está fazendo para combatê-la e minimizar seus efeitos, conforme as recomendações da OMS. Especialmente na Região Nordeste, a partir das iniciativas do Consórcio Nordeste (Consórcio NE), os estados da região uniram-se para, em esforço conjunto, dirimir os efeitos da Pandemia do Covid-19, destacando, entre as iniciativas, a criação do Comitê Científico de Combate ao Coronavírus ${ }^{5}$, que congrega informações sobre a pandemia, monitoramento em tempo real a nível estadual e municipal, serviço de clipping, além de boletins e comunicados a respeitos de demais ações de mesma natureza. O sucesso do Comitê foi tamanho que o Consórcio NE ampliou, por exemplo, seu monitoramento para estados fora da região Nordeste.

Além desta iniciativa conjunta, cada estado adotou também a comunicação por meio de redes sociais tais quais Facebook, Instagram e Twitter. Essa possibilidade ajuda a viabilizar o trânsito de informações oficiais em plataformas mais amplamente acessadas pela população. Vale destacar que, segundo levantamento realizado pelo DataSenado (BRASIL; BRASIL, 2019), no ano de $2019^{6}, 83 \%$ da população brasileira acredita que as redes sociais influenciam na opinião das pessoas, por vezes, influenciando suas ações, como o voto, o que também é aferido pelo DataSenado, na mesma pesquisa (BRASIL; BRASIL, 2019). Neste sentido, é incontroverso afirmar que as redes sociais, hodiernamente, ocupam lugar de destaque nas práticas infocomunicacionais brasileiras, configurando-se como meios alternativos para as instituições governamentais chegarem até o público pretendido, a própria população.

Este movimento ocorre graças ao ingresso e popularização de gadgets, ou seja, de aparelhos portáteis tais como smartphones e tablets e da própria internet, tanto domiciliar, como em pacote de dados, que tiveram seus processos de criação e desenvolvimento incentivados pelos setores industrial e de Ciência e Tecnologia (C\&T), percebendo neste desenvolvimento, uma possibilidade infocomunicacional de acelerar a economia de países investidores, bem como as práticas de vigilância, as quais Schoshana Zuboff (2018) chama de capitalismo de vigilância. Este capitalismo de vigilância, nas palavras de Zuboff (2018) seria uma nova forma de capitalismo de informação, que "[...] procura prever e modificar o comportamento humano como meio de produzir receitas e controle de mercado [...] incorporando novas políticas e relações sociais [...]" (ZUBOFF, 2018, p. 18). A autora também evidencia, para além das questões sócio-econômicas, que há uma dualidade que caracteriza as Tecnologias da Informação (TI), ligada primeiramente à substituição do ser humano por máquinas, cujo controle e a continuidade são mais observáveis e, em segunda instância, "[...] a automação gera simultaneamente informação que proporciona um nível mais profundo de transparência a atividades que pareciam parcial ou totalmente opacas" (ZUBOFF, 2018, p. 20). Neste sentido, a mediação pelo computador "[...] representa simbolicamente eventos, objetos e processos, que se tornam visíveis, passíveis de serem conhecidos e compartilhados de uma nova maneira" (ZUBOFF, 2018, p. 20). Essas percepções de Zuboff (2018) são importantes para compreender o trânsito das possibilidades informacionais de órgãos públicos para as redes sociais, por entender que estão são também terrenos habitáveis, passíveis de comunicabilidades que certamente, em meios tradicionais, não se tivesse igual ou semelhante alcance.

Isso ocorre pois, como assevera Castells (2019), as tecnologias ascendem e ajudam a constituir um novo modelo de sociedade, pautado não mais na comunicação unilateral, mas na perspectiva das interações em rede, que constitui a "nova

\footnotetext{
${ }^{5}$ Ver mais em: https://www.comitecientifico-ne.com.br/c4ne. Acesso em: 20 jun. 2020.

${ }^{6}$ Foram entrevistados 2.400 cidadãosque têm acesso à internet, em todas as unidades da federação, por meio de ligações para telefones fixos e móveis, no período de17 a 31 de outubro. A amostra é estratificada, totalmente probabilística, com alocação proporcional à população segundo olBGE. A margem de erro é de dois pontos percentuais com nível de confiança de $95 \%$. Algumas questões foram respondidas por grupos específicos da amostra. Para estas questões a margem de erroé superior a dois pontos percentuais.
} 
morfologia social" (CASTELLS, 2019, p. 533), pautada fortemente pelas TIC. Conforme versa o autor "A presença na rede ou ausência dela e a dinâmica de cada rede em relação às outras são fontes cruciais de dominação e transformação de nossa sociedade: uma sociedade que, portanto, podemos chamar apropriadamente de sociedade em rede [...]" (CASTELLS, 2019, p. 533). A presença dos órgãos municipais, estaduais e federais, neste sentido, nos ambientes sócio-digitais não somente promove a informação por eles produzidas e disseminadas, como demarca seus territórios digitais, como forma de estar mais próximos da população.

Essa disputa de poder pode ser percebida, inclusive, pela própria criação do Consórcio NE, que se constituiu a partir do receio dos governadores e prefeitos da Região de que o governo federal não atendesse seus anseios e demandas a contento. Conforme Holanda (2019); Fragão (2019) apontam, o então presidente, Jair Messias Bolsonaro, fez afirmações e colocações de cunho discriminatório, em relação à região, classificando os nordestinos como 'paraíbas' e afirmando que "a única coisa que presta no Maranhão é o presídio de Pedrinhas"7 (FRAGÃO, 2019). Diante do impasse, a criação do Consórcio, criado em 2019, tem como proposta ser "[...] uma ferramenta para atrair investimentos e alavancar projetos de forma integrada para a região. Dentre as possibilidades abertas estão a realização de compras conjuntas e a implementação integrada de políticas públicas, como nas áreas de educação e segurança" (MAIA, 2019, não paginado).

Em relação a pandemia, o reforço deste receio pode ser percebido pela reiterada política negacionista do governo federal, especialmente, do atual presidente da República que, em primeiro momento, asseverou ser apenas uma 'gripezinha' (CONGRESSO EM FOCO, 2020), a Covid-19 e, mais adiante, que tanto o isolamento horizontal era exagero/'tirania' (UOL, 2020; VALFRÉ, 2020; O GLOBO, 2020), como o uso da hidroxcloroquina era uma alternativa efetiva, mesmo com testes reiterados que comprovaram a alta taxa de mortalidade na administração da substância (KER; CAMBRICOLI; VARGAS, 2020) e das ressalvas tanto do Ministério da Saúde e da OMS (FERNANDES, 2020; MAZUI, 2020), advindas destes testes e estudos. Além disso, corrobora com esta celeuma inter-autárquica, as críticas do presidente Bolsonaro às ações independentes dos governos estaduais e municipais, que tiveram de ser asseguradas pelo Superior Tribunal Federal (AMORIM, 2020; TEIXEIRA, 2020), para garantir o êxito nas ações de combate à pandemia do novo coronavírus.

Em meio a esse contexto e como reflexo da territorialização dos nos meios digitais, especialmente nas redes sociais digitais, o Consórcio Nordeste habilitou perfis em redes sociais como Instagram e Facebook e seu comitê científico divulga os dados, com periodicidade, por meio do Projeto Mandacaru. Além destas ações convergentes e uníssonas, os nove estados ${ }^{8}$ do Nordeste, cada qual, tem suas páginas institucionais nas referidas redes sociais. Para fins deste estudo, a rede social Instagram é a escolhida, dado que, entre os brasileiros com faixa etária de 16 a 29 anos, $41 \%$ utilizam-na como fonte de informação. Entre as pessoas cuja faixa de idade varia de 30 a 39 anos, essa percentagem decresce para 32\% (Ver Gráfico 1). Essas duas parcelas da pesquisa do DataSenado (BRASIL; BRASIL, 2019) são de importante destaque, uma vez que estes são os maiores vetores de transmissão do coronavírus, conforme dados do Portal Covid-19 Brasil (AZEVEDO, 2020).

\footnotetext{
7 O Complexo Penitenciário São Luís, conhecido como Presídio de Pedrinhas, ficou conhecido pela chacina ocorrida em seu interior, após sucessivas rebeliões de presos, entre os anos de 2013 e 2014, que resultou na decaptação de aproximadamente 64 encarceirados. O presídio juntara facções rivais em seu interior, o que causou a situação de barbárie no local, além da superlotação. Somente na gestão de Flávio Dino, houve uma reestruturação do Complexo e a separação de presos que pudessem desencadear situação análoga (PITOMBO, 2019).

${ }^{8}$ Alagoas, Bahia, Ceará, Maranhão, Paraíba, Pernambuco, Piauí, Rio Grande do Norte e Sergipe.
} 
Gráfico 1 - Frequência com que os respondentes utilizam os Instagram como fonte de informação

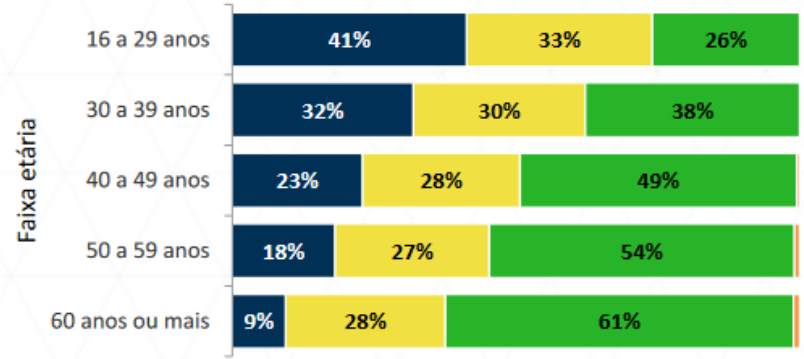

- Sempre às vezes " Nunca = Não sei ou prefiro não responder
Gráfico 2 - Número de infectados por faixa etária no Brasil até maio de 2020

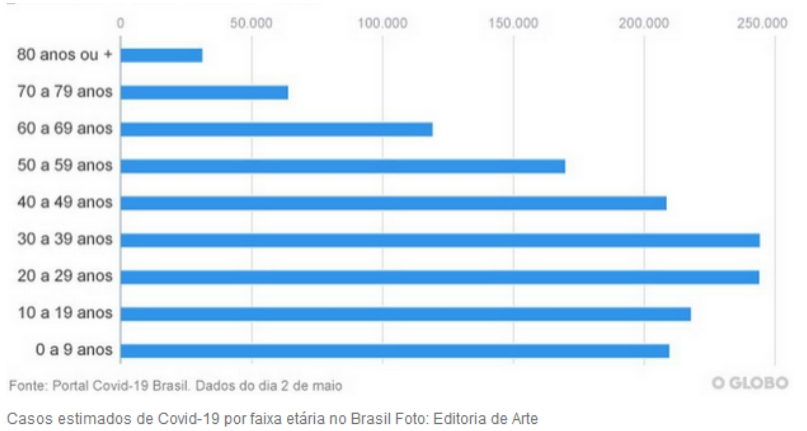

Fonte: Brasil (2019, p. 4).

Fonte: Azevedo (2020).

O levantamento aponta que a taxa maior de infectados está entre brasileiros de 20 a 30 anos, que são a parcela ativa da população. Logo abaixo, estão os de 10 a 19 anos e de 40 a 49 anos. Portanto, é premente que esta faixa etária carece de maiores cuidados, sobretudo informacionais, para que a curva de crescimento desacelere e, por fim declina. Neste sentido, a comunicação dos governos estaduais e municipais com este público é não somente viável como tem maior possibilidade de surtir efeito que por canais menos populares entre estes jovens. Portanto, há uma potencialidade da plataforma Instagram pervadir a bolha etária acima evidenciada. O Instagram é uma rede social cujo principal objetivo é o compartilhamento de conteúdos imagéticos e audiovisuais. Sua trajetória pode ser observada conforme Figura 1, que mostra a cronologia desde sua criação, ainda como Burbn, ao surgimento das lives, que são interações ao vivo, na plataforma.

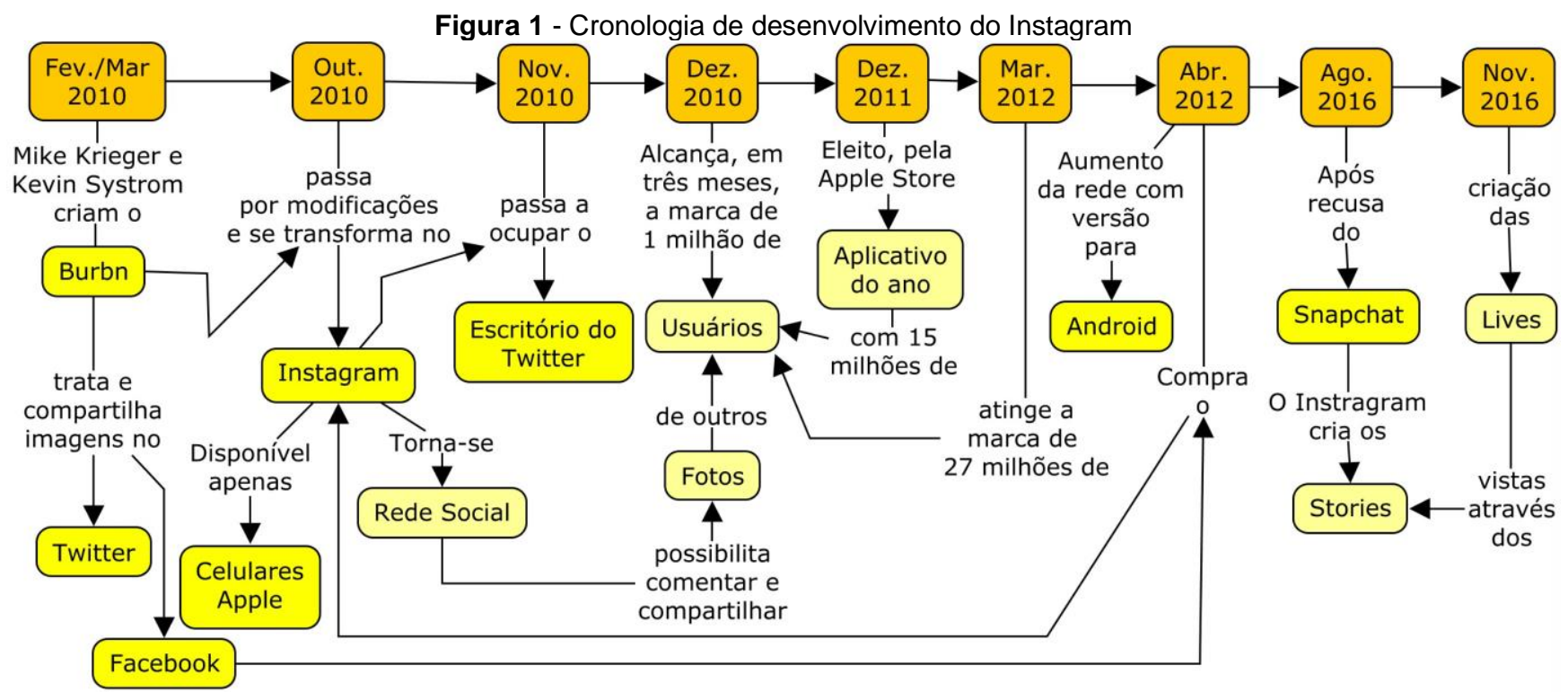

Fonte: A autoria, adaptado e atualizado de Sampaio, Lima, Rosa e Oliveira (2018, p. 74).

A criação de Krieger e Systrom, a priori, era exclusivamente para manipulação de fotos compartilháveis via Twitter e Facebook, no entanto, enxergou-se um potencial no aplicativo que, em outubro de 2010, passou a ser chamado de Instagram, cuja dinâmica de compartilhamento de fotos e vídeos, a priori, de até 60 segundos, permitia, e ainda hoje permite, interações como curtidas, comentários e replicação destes materiais pelos usuários da rede. Com vistas ao maior alcance desses materiais, o Instagram utiliza hashtags, ou etiquetas, como forma de aproximar usuários de gostos afins, bem como fazer pervadir assuntos em alta na plataforma (SAMPAIO; LIMA; ROSA; OLIVEIRA, 2018). Tomando por exemplo o atual cenário da Covid-19, ao 
buscar por este termo e demais relacionados ao vírus (Coronavirus, SARS-CoV-2), publicações, as mais diversas, são recuperadas, de múltiplos perfis, sejam estes produtores de informação jornalística, memes, institucionais, pessoais etc., o que facilita as interações na plataforma. No ano de 2017, o Instagram passa a permitir que seus usuários possam seguir as hashtags criadas na plataforma (SAMPAIO; LIMA; ROSA; OLIVEIRA, 2018). Percebendo o crescimento do Instagram, Mark Zuckerberg (CEO e criador do Facebook) compra a plataforma. Paralelo a este movimento interorganizacional, o Instagram passa a ganhar usuários diversos, perfis jornalísticos, institucionais e adota o selo de verificação como forma de sinalizar os perfis oficiais de grandes organizações e instituições, bem como de personalidades.

Outras ferramentas e recursos foram acrescidos ao Instagram, como os Stories, que são publicações instantâneas, cuja permanência na página do usuário é de vinte e quatro horas e o lgTV, que possibilita o ingresso de vídeos acima de sessenta segundos na plataforma. Esses recursos são de importante destaque pois, como afirmam Sampaio; Lima; Rosa; Oliveira, (2018), a configuração inicial do Instagram estava fortemente ligada ao imediatismo e apelo imagético. Segundo as autoras, "as imagens são produzidas com o intuito de gerar resposta imediata dos que a veem, são termômetro sociais. Portanto, quão mais enxutas e quão significativas em si, melhor" (SAMPAIO; LIMA; ROSA; OLIVEIRA, 2018, p. 75). Essa afirmação de Sampaio, Lima, Rosa e Oliveira (2018) se dá, pois, apensar dos recursos e tempo de vídeo ampliados, o recurso textual do Instagram é pouco explorado, havendo limite de caracteres para a descrição ou comentários e a própria arquitetura da plataforma privilegia mais o apelo imagético ao textual.

Certamente por isso, o Instagram tem crescido tão rápido, em tão pouco tempo, por possibilitar que esse homo photographicus dê vazão às suas criações e recriações de si. Nesse sentido, a narrativa dos fatos, no Instagram, é mais limitada, dado que os conteúdos devem ser sucintos e envoltos em estímulos visuais diversos. Isso gera menor aprofundamento das discussões, potencializado pela limitação das legendas e pela limitação do espaço de comentários (SAMPAIO; LIMA; ROSA; OLIVEIRA, 2018, p. 75).

Neste sentido, as estratégias informacionais precisam ser pensadas e empreendidas na perspectiva de dar maior aderência, em meio à liquidez das interações em rede, às orientações destes estados e municípios a respeito da Covid-19. Porque há um público potencial que é tocado por esta linguagem mais fluida, instantânea e obsolescente, como há, também, uma pervasividade de canais e publicações diversas, ou seja, uma produção demasiada de conteúdos (CASTELLS, 2015; 2019) na plataforma, somada, e não se pode deixar de destacar, à pós-verdade. Movimento que se desenha na contemporaneidade e que pontua a aderência dos sujeitos sociais a partir de suas afetividades e perspectivas ideológicas (D'ANCONDA, 2018) em detrimento da racionalização dos processos informacionais.

\section{Procedimentos Metodológicos}

O conhecimento empírico é a manifestação da consciência do conhecer e se colocar no mundo. É esta consciência que conduz qualquer pesquisador no seu caminhar em busca do conhecer. Neste sentido, nosso percurso metodológico amparase na pesquisa do tipo descritiva, que conforme seu nome sugere descreve os fatos e fenômenos de uma determinada realidade (TRIVIÑOS, 1987). Utilizou-se ainda a ARS, um método que surgiu no âmbito da sociologia, da psicologia social e da antropologia (SILVA; MATHEUS, 2006) que permite compreender o impacto do fluxo informacional mediado pelas redes na vida em sociedade.

Marteleto (2001, p. 72) afirma que a "[...] análise de redes estabelece um novo paradigma na pesquisa sobre a estrutura social. [...] A estrutura é apreendida concretamente como uma rede de relações e de limitações que pesa sobre as escolhas, as orientações, os comportamentos, as opiniões dos indivíduos".

A abordagem do tratamento dos dados foi quali-quantitativa, uma vez que apresenta tipologia adequada às ciências sociais (CRESWELL; CLARK, 2007) e permitirá comparar e contrastar os dados coletados estatisticamente com a inferência subjetiva da abordagem qualitativa.

\subsection{Coleta de dados e análise preliminar}

O corpus investigativo é composto pelos estados do Ceará, Maranhão e Pernambuco, por estes concentrarem os maiores índices de infectados e óbitos do Nordeste em 26 de abril de 2020, exatamente dois meses após a confirmação do primeiro 
caso no país. Segundo o Portal Coronavírus Brasil (www.covid.saude.gov.br), com os dados atualizados em 26 de abril de $2020^{9}$, os três estados são os três primeiros no ranking de casos confirmados e óbitos da região.

Quadro 1 - Corpus Investigativo e Ranking por número de casos confirmados e óbitos

\begin{tabular}{|c|c|c|c|c|}
\hline RANKING & ESTADO & PERFIL NO INSTAGRAM & CONFIRMADOS & ÓBITOS \\
\hline $1^{\circ}$ & Ceará & @governodoceara & 5.833 & 327 \\
\hline $2^{\circ}$ & Pernambuco & @governope & 4.898 & 415 \\
\hline 3은 & Maranhão & @governoma & 2.223 & 112 \\
\hline $4^{\circ}$ & Bahia & @govba & 2.209 & 73 \\
\hline $5^{\circ}$ & $\begin{array}{l}\text { Rio Grande } \\
\text { do Norte }\end{array}$ & @governodorn & 825 & 44 \\
\hline $6^{\circ}$ & Alagoas & @governodealagoas & 554 & 32 \\
\hline $7^{\circ}$ & Paraíba & @govparaiba & 499 & 49 \\
\hline $8^{\circ}$ & Piauí & @governodopiaui & 331 & 18 \\
\hline 9은 & Sergipe & @governosergipe & 159 & 9 \\
\hline
\end{tabular}

Fonte: Portal Coronavírus Brasil (dados até 26/04/2020).

A coleta dos dados foi realizada nos perfis oficiais do Instagram dos governos dos estados do Ceará, Pernambuco e Maranhão, do período de 26 de fevereiro a 26 de abril de 2020, por meio de coleta manual e transportados para o Excel. Foram coletados os seguintes metadados: link para o post original, data, conteúdo da legenda do post e número de curtidas. Após exaustiva análise textual das publicações, cada post foi classificado de acordo com oito categorias: Ação de conscientização, cultura e/ou solidariedade; Boletim/Estatística; Combate a fake news; Histórias, agradecimentos e homenagens; Informes e orientações; Outros; Políticas de enfrentamento; e Prevenção. Ao todo, foram monitoradas 1.008 publicações realizadas pelos estados em seus respectivos perfis. A seguir, o enfoque de cada categoria.

Quadro 2 - Categorias adotadas na classificação dos posts dos governos dos estados

\begin{tabular}{|c|c|}
\hline CATEGORIA & ENFOQUE \\
\hline $\begin{array}{l}\text { Ação de conscientização, cultura } \\
\text { e/ou solidariedade }\end{array}$ & $\begin{array}{l}\text { Campanhas e mensagens para conscientizar a população a ficar em casa, } \\
\text { ações culturais para entretenimento dos cidadãos em isolamento e ações } \\
\text { solidárias para ajudar as pessoas em situações de risco e vulnerabilidade } \\
\text { durante a pandemia. }\end{array}$ \\
\hline Boletim/Estatística & $\begin{array}{l}\text { Números dos casos da Covid-19: investigados, prováveis, descartados, } \\
\text { confirmados, óbitos, recuperados. }\end{array}$ \\
\hline Combate a fake news & $\begin{array}{l}\text { Mensagem de conscientização sobre o malefício das fake news, checagem } \\
\text { de fatos, divulgação dos canais oficiais para informação confiável. }\end{array}$ \\
\hline $\begin{array}{l}\text { Histórias, agradecimentos e } \\
\text { homenagens }\end{array}$ & $\begin{array}{l}\text { Histórias de pessoas recuperadas da Covid-19, homenagens aos } \\
\text { profissionais que trabalham no combate à doença, sobretudo aos } \\
\text { profissionais de saúde, e agradecimento à população que seguiu o } \\
\text { isolamento. }\end{array}$ \\
\hline Informes e orientações & $\begin{array}{l}\text { Informes sobre funcionamento de órgãos e instituições durante o período da } \\
\text { pandemia; informes sobre pronunciamentos e reuniões do governo do } \\
\text { estado; informes sobre ações pontuais e sobre os canais oficiais do governo; } \\
\text { orientações de como proceder em casos de suspeita de infecção da Covid- } \\
19 .\end{array}$ \\
\hline Outros & $\begin{array}{l}\text { Conteúdo não relacionado à Covid-19 e/ou sem nenhuma menção à doença, } \\
\text { seja por legenda, imagem ou hashtag. }\end{array}$ \\
\hline Políticas de enfrentamento & $\begin{array}{l}\text { Ações formais do governo do estado no enfrentamento à Covid-19: } \\
\text { contratações de profissionais da saúde, distribuição de equipamentos, } \\
\text { criação e estruturação de leitos e hospitais, decretos de medidas restritivas, } \\
\text { medidas de apoio aos setores da indústria, comércio e serviços, isenção de } \\
\text { impostos e ações e programas de auxílio à população de baixa renda. }\end{array}$ \\
\hline Prevenção & $\begin{array}{l}\text { Dicas para evitar a contaminação: uso de máscara, distância mínima, lavar as } \\
\text { mãos, ficar em casa, higienização dos objetos. }\end{array}$ \\
\hline
\end{tabular}

Fonte: Autoria própria (2020).

Neste sentido, as categorias (ver Quadro 2) foram representadas e explicitadas pelas relações de significância que se estabelecem com as publicações, a fim de apresentar inferências na conexão entre os conteúdos postados e as estatísticas da Covid-19 em cada estado. Esses parâmetros conferem cientificidade às análises, pois revelam informações importantes

${ }_{9}^{9}$ Disponível em: https://covid.saude.gov.br/. Acesso em: 28 maio 2020. 
relacionadas às publicações dos perfis dos estados. Embora se constituam em representações artificiais elaboradas pelos pesquisadores deste estudo, evidenciam-se os aspectos que serão observados na construção de conteúdo gerados por perfis governamentais nas Redes Sociais Online, mais especificamente no Instagram.

\section{Resultados e discussão}

As dinâmicas informacionais discutidas nessa seção estão relacionadas movimento e progresso dos conteúdos postados pelos governos dos estados do Ceará, Maranhão e Pernambuco e foram analisadas a partir das categorias elencadas no Quadro 2. A classificação foi feita em um corpus de 1.008 posts recuperados, no período de 26 de fevereiro de 2020 a 26 de abril de 2020, distribuídos por estado de acordo com o Gráfico 3 e por volume diário, conforme o Gráfico 4.

Gráfico 3 - Volume de publicações por estado

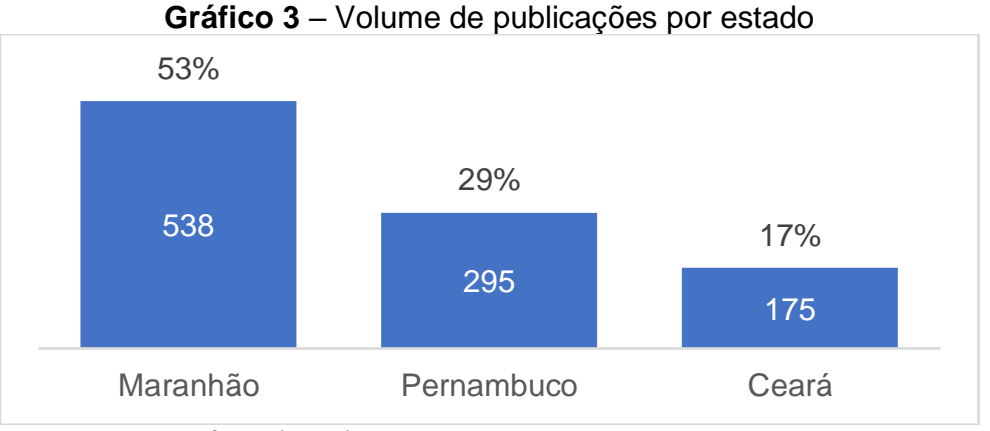

Fonte: Autoria própria (2020).

O governo maranhense foi o mais ativo durante o período analisado. Ao total, foram 538 publicações nos dois meses monitorados, respondendo por $53 \%$ dos posts realizados pelos perfis. Os pernambucanos registraram o segundo maior volume de publicações, com 295 posts e uma média de quase 5 postagens por dia. Os cearenses foram os menos ativos entre os players analisados, com 175 posts.

Gráfico 4 - Volume diário de publicações por estado

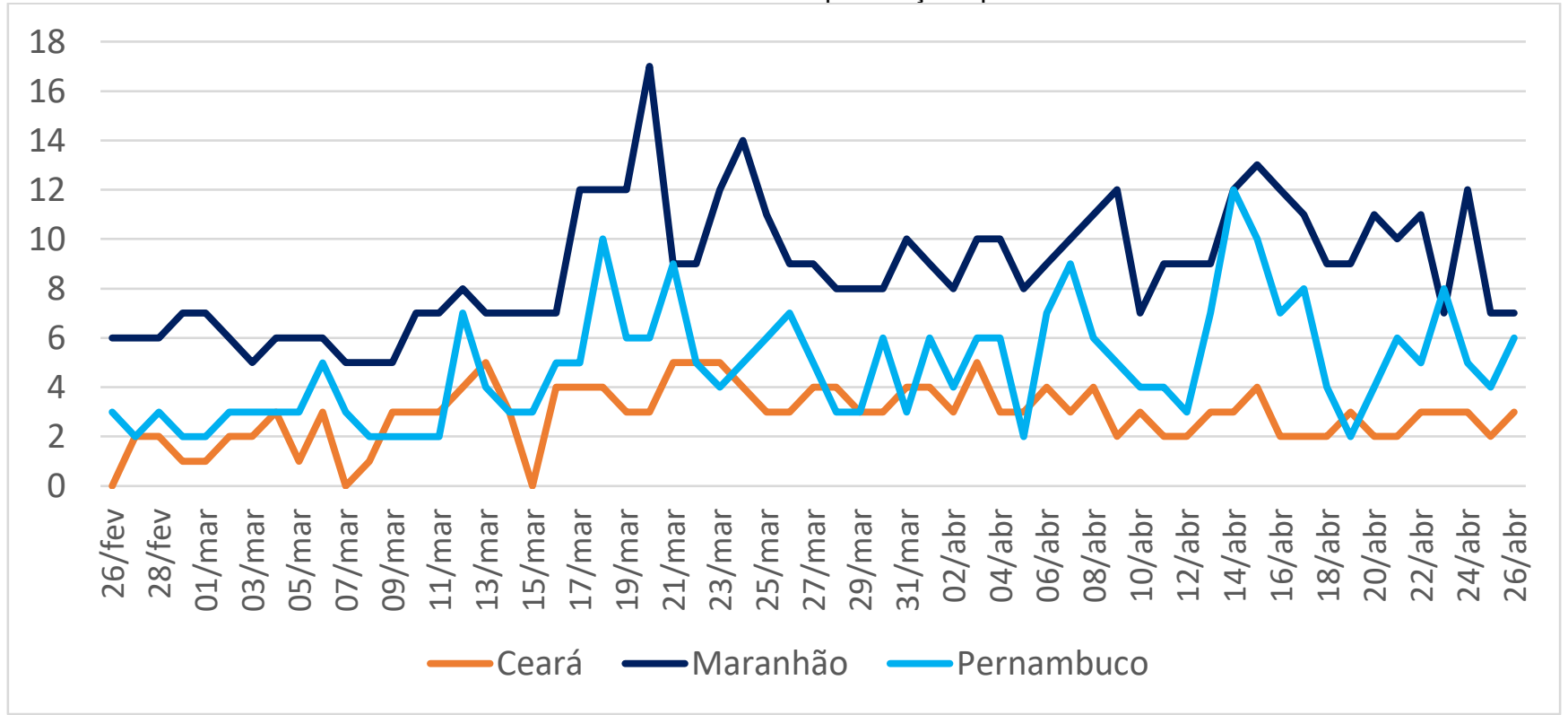

Fonte: Autoria própria (2020).

Pode-se observar, também, o quantitativo de posts de cada categoria por estado, conforme o Gráfico 5. Observa-se que, somando os três estados, majoritariamente, prevalecem as categorias 'Outros' e 'Políticas de enfrentamento', o que demonstra um número significativo de posts não relacionados à Covid-19 e, quando relacionados, esses posts denotam políticas e medidas de combate à doença por parte do governo do estadual. Mais da metade dos posts $(56 \%)$ se concentram nessas 
duas categorias, mas apenas Maranhão e Ceará têm a categoria 'Outros' como a primeira do ranking no desenvolvimento dos seus conteúdos, em Pernambuco a categoria preponderante é 'Políticas de enfrentamento'.

Gráfico 5 - Volume de publicações por categoria abordada pelos governos dos estados

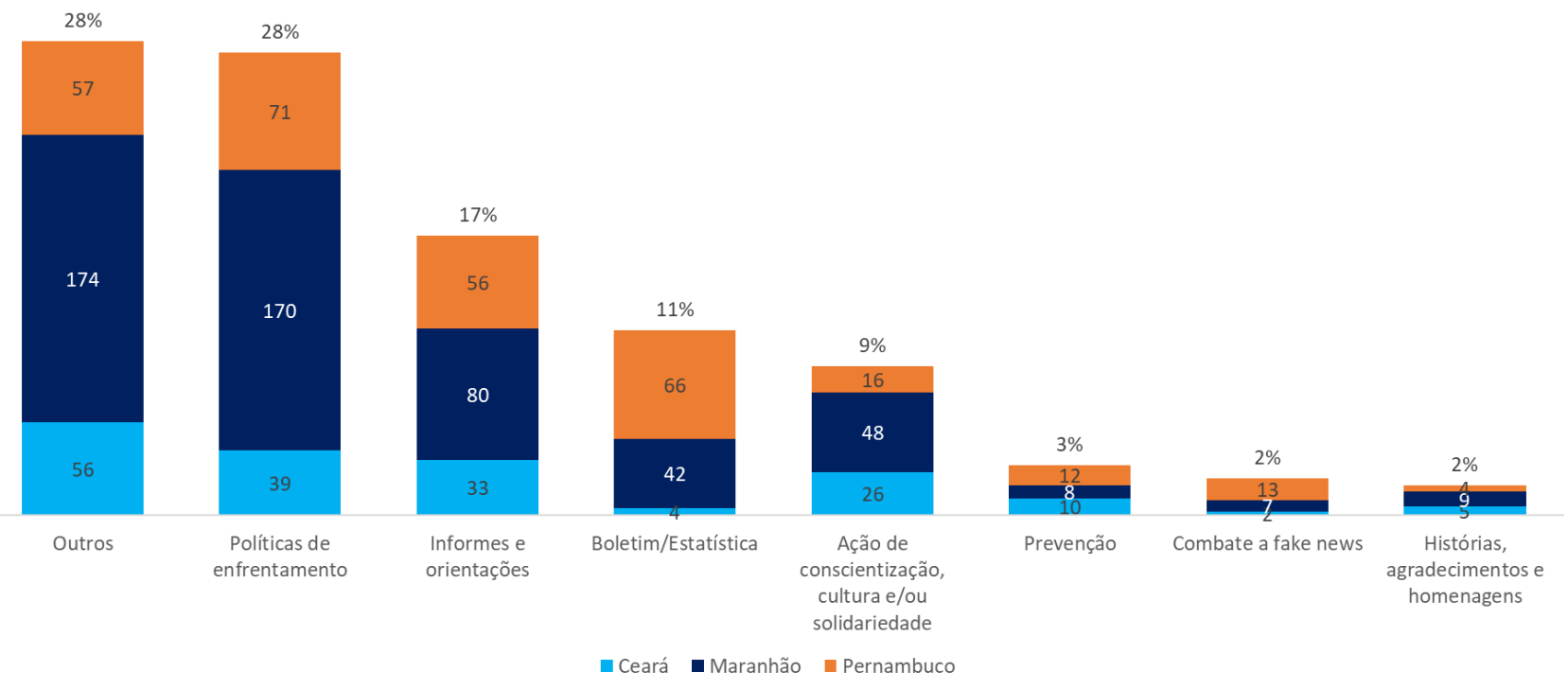

Fonte: Autoria própria (2020).

No Maranhão, estado com maior volume de posts (538), sobressaem-se as categorias 'Outros' (32\%), 'Políticas de enfrentamento' (32\%) e 'Informes e orientações' (15\%), com destaque para 'Políticas de enfrentamento', que faz parte da dinâmica de publicações do estado desde 12 de março, oito dias antes dos primeiros casos de infecção serem confirmados (20 de março), sendo essa uma categoria recorrente até 26 de abril. Vale salientar, aqui, que o governo do Maranhão fez uma autopromoção por ser o primeiro estado do Brasil em ter um centro de testagens para a Covid-19. Já a categoria 'Informes e orientações' iniciou seu movimento em $1^{\circ}$ de março com o propósito de informar à população sobre como o governo estava agindo diante da situação de pandemia, sua preparação para atender possíveis pacientes e divulgação dos canais de comunicação governamentais e orientações sobre os sintomas da doença. Ressalta-se que, inicialmente, o governo do Maranhão reforçava durante alguns posts desta categoria o fato de ainda não haver casos confirmados no estado e, após os primeiros casos, reforçou-se, inclusive, o fato de estar abaixo da média nacional de infectados.

As demais categorias, embora com menos representatividade, também apresentaram uma dinâmica particular. A categoria de 'Ação de conscientização, cultura e/ou solidariedade' (9\%) teve destaque com a ação 'Conexão Cultural', da Secretaria de Cultura do estado, com apresentações online como entretenimento à população, além da campanha de conscientização protagonizadas por artistas maranhenses, estimulando as famílias a postar foto ou vídeo com a hashtag \#MaranhãoFicaEmCasa. Já a categoria 'Boletim/Estatística' (8\%) se mostrou presente a partir de 03 de março (dezessete dias antes da confirmação do primeiro caso, em 20 de março), mas se tornou diária apenas a partir de $1^{\circ}$ de abril. A categoria 'Histórias, agradecimentos e homenagens' (2\%) concentra no mês de abril as homenagens e os agradecimentos aos profissionais de saúde, seguido dos agradecimentos àqueles que doaram para ajudar no enfrentamento da pandemia. Enquanto isso, a categoria 'Prevenção' (1\%) tem posts dispersos desde o fim de fevereiro, segunda metade de março e penúltima semana de abril. Em relação ao 'Combate a fake News', não houve significativa dedicação por parte do estado, tendo apenas poucos posts distribuídos entre penúltima semana de março e início de abril. 


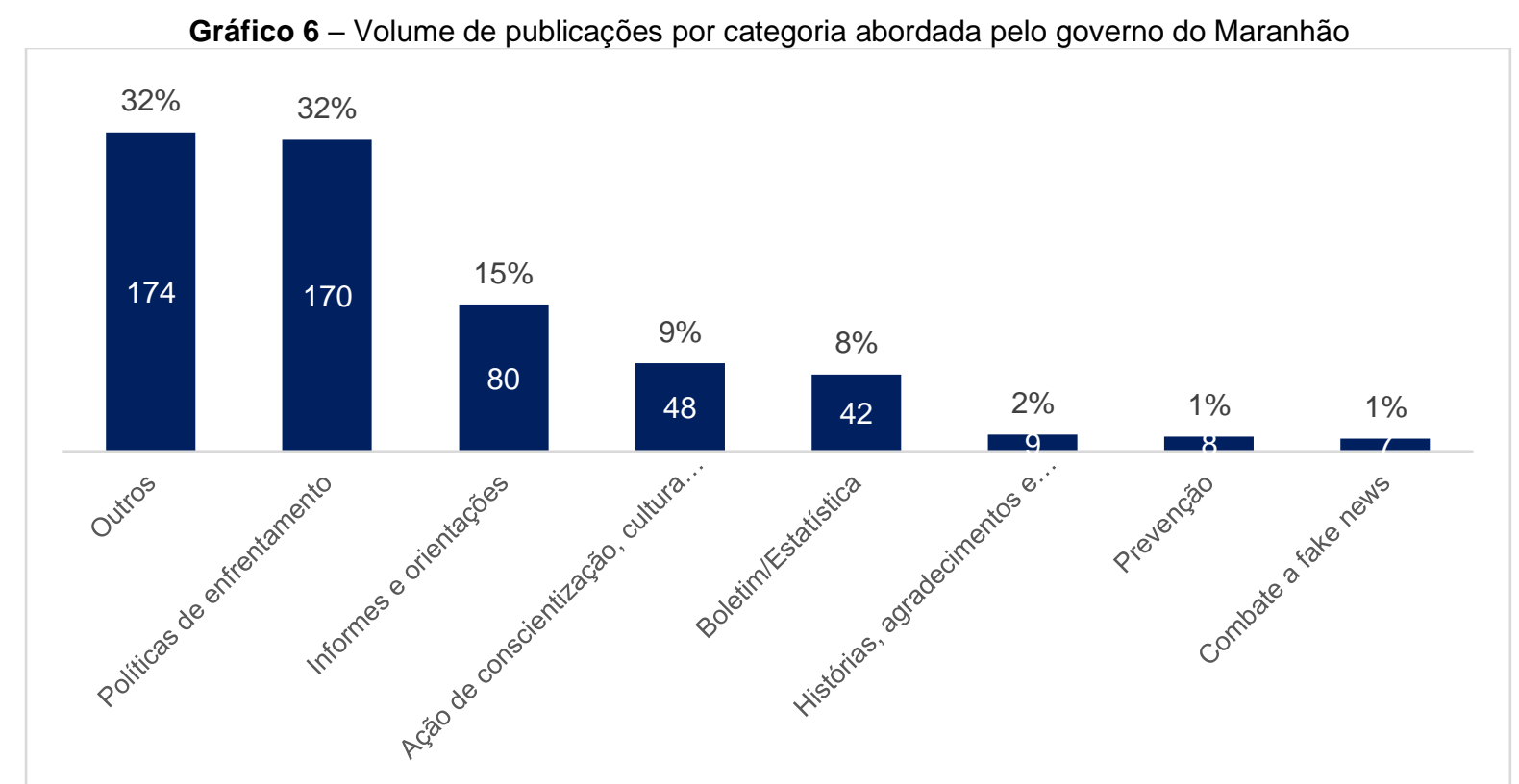

Fonte: Autoria própria (2020).

Quando se analisa a evolução diária dos posts do governo do Maranhão, conforme Gráfico 7, fica evidente que a categoria 'Políticas de enfrentamento' é bastante representativa mesmo antes dos primeiros casos confirmados do novo coronavírus, com um pico no dia 20 de março, dia com maior número de posts (17) pelo governo (ver Gráfico 4) e dia do primeiro caso confirmado de infecção pela Covid-19 no estado. Outra observação é a perda de força da categoria 'Outros'.

Gráfico 7 - Evolução diária de publicações por categoria no Maranhão

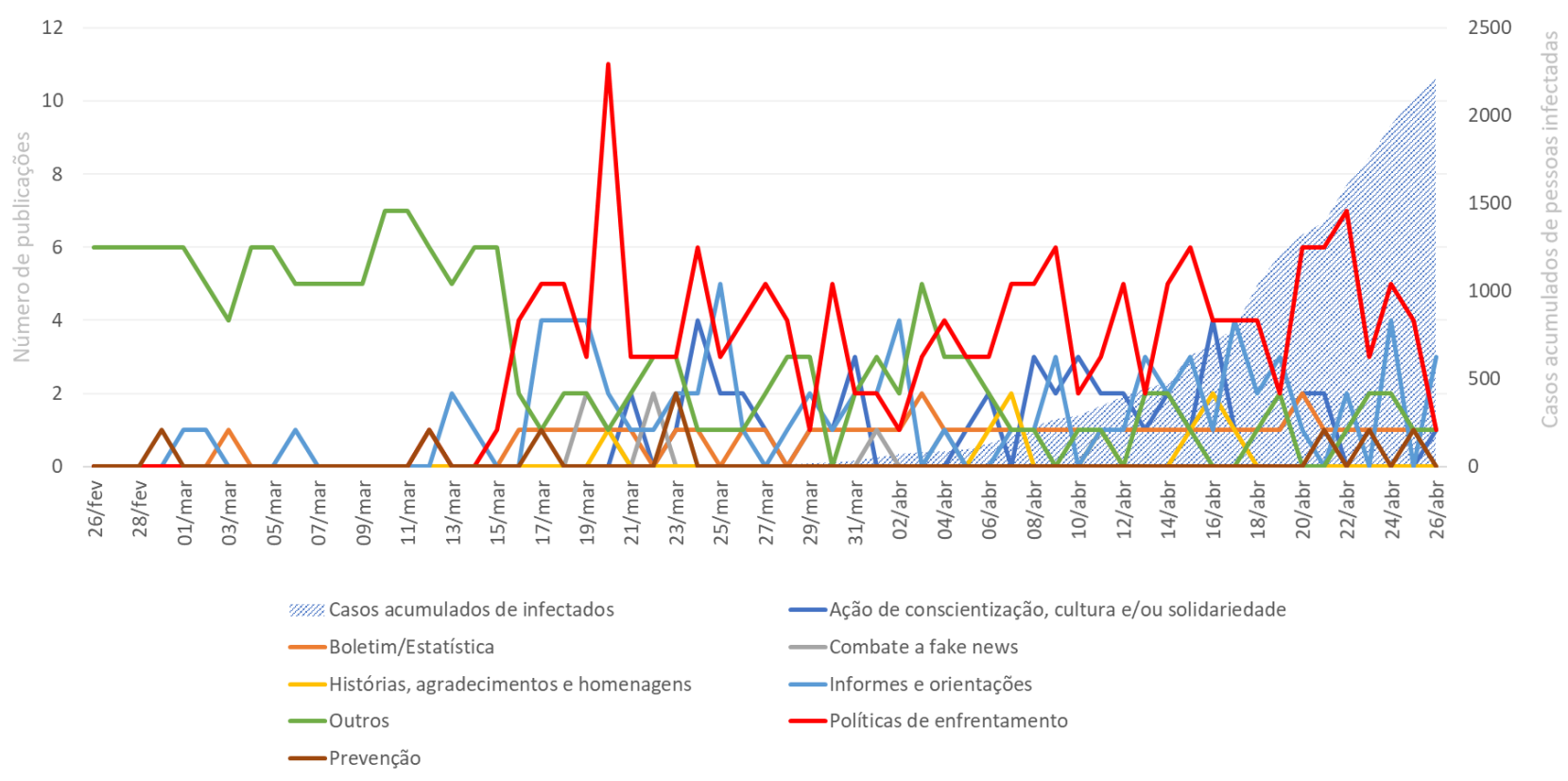

Fonte: Autoria própria (2020).

Dos 295 posts no Instagram do governo do estado de Pernambuco, destacam-se as três categorias predominantes: 'Políticas de enfrentamento' (24\%), 'Boletim/Estatística' (22\%) e 'Outros' (19\%), empatatada com 'Informes e orientações' (19\%), como 
se observa no Gráfico 5. O conteúdo dos posts do estado concentrou-se em mostrar aos seguidores as medidas de combate à Covid-19 executadas pelo governo, bem como em mostrar diariamente as estatísticas de casos confirmados, óbitos e recuperados da doença. Vale ressaltar que, especificamente, a publicação de posts relacionados à categoria 'Boletim/Estatística' passou a ser diária em 14 de março de 2020, dois dias após os primeiros casos de infecção confirmados no estado (12 de março). A mesma dinâmica é percebida na categoria 'Políticas de enfrentamento', que inicia um progresso nas publicações em 13 de março e assim perdura até 26 de abril de 2020 em uma evidência da preocupação do governo estadual de Pernambuco em divulgar suas ações formais de medidas restritivas e de subsídio à população. Seguindo o mesmo movimento, a categoria 'Informes e orientações' também se torna mais frequente em 15 de março, também logo após os primeiros casos confirmados, acompanhando uma tendência de informar à população sobre como deve agir diante das suspeitas e casos de infecção, bem como orientando sobre o funcionamento das instituições, destacando-se a autopromoção em torno do estado, que mais de uma vez esteve em primeiro lugar no ranking da transparência entre todos os estados do país.

Ademais, as categorias com percentual menor no estado consolidaram suas dinâmicas de maneira distinta. Em 'Ação de conscientização, cultura e/ou solidariedade' (5\%), os posts foram sobres doação de sangue, conscientização à população para evitar sair de casa e a campanha Pernambuco Solidário, estimulando a participação da sociedade na ação solidária. $O$ início dos posts dessa categoria coincidiu com o primeiro caso confirmado da doença no estado (12 de março) e encerrou na metade de abril (considerando o período analisado). Já na categoria 'Combate a fake News' (4\%), Pernambuco concentrouse em realizar checagem de fatos, desmentindo boatos, iniciando esse processo em 18 de março, também após a notificação dos primeiros casos. A categoria 'Prevenção' (4\%), com posts de dicas para evitar a contaminação, teve seu movimento de maneira dispersa, distribuindo-se entre o fim de fevereiro até início da segunda semana de abril. O primeiro post sobre a Covid-19 pelo governo do estado foi nessa categoria (em 28 de fevereiro de 2020). Enquanto isso, a categoria 'Histórias, agradecimentos e homenagens' (1\%) tem raros posts que denotam, em sua maioria, homenagens e agradecimentos aos profissionais de saúde.

Gráfico 8 - Volume de publicações por categoria abordada pelo governo de Pernambuco

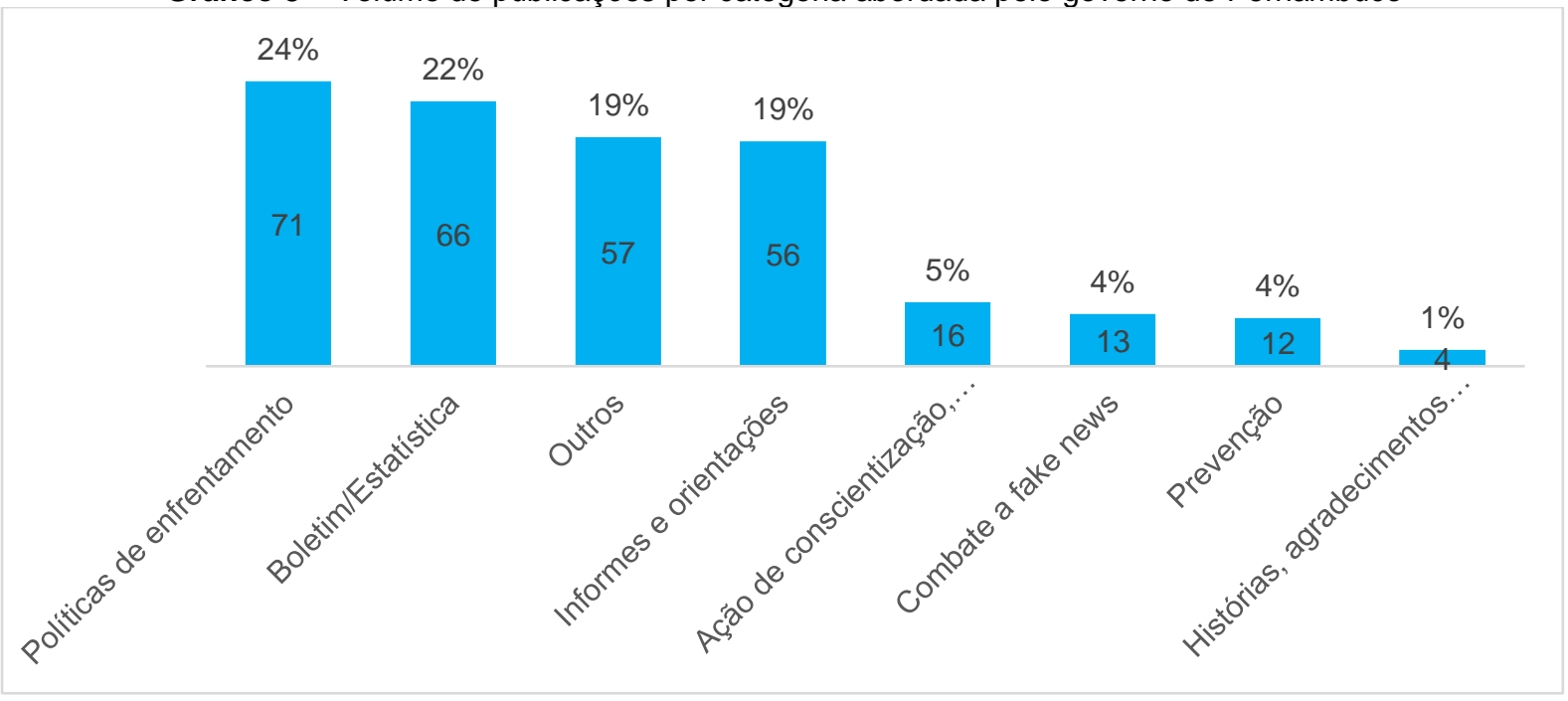

Fonte: Autoria própria (2020).

A dinâmica informacional de Pernambuco se mostrou consistente em relação às categorias, com uma manutenção dos posts em cada uma delas. Assim como o Maranhão, a categoria 'Outros' perde a força à medida em que aparecem os primeiros casos confirmados, observa-se que no dia 13 de março, um dia após os primeiros casos confirmados, essa categoria cai e não volta mais à evidência. As categorias 'Políticas de enfrentamento' e 'Ação de conscientização, cultura e/ou solidariedade' também se tornam mais evidentes nos dias 18 e 19 de março, respectivamente, poucos dias após a confirmação dos primeiros casos da Covid-19 no estado, em 12 de março de 2020. 
Gráfico 9 - Evolução diária de publicações por categoria em Pernambuco

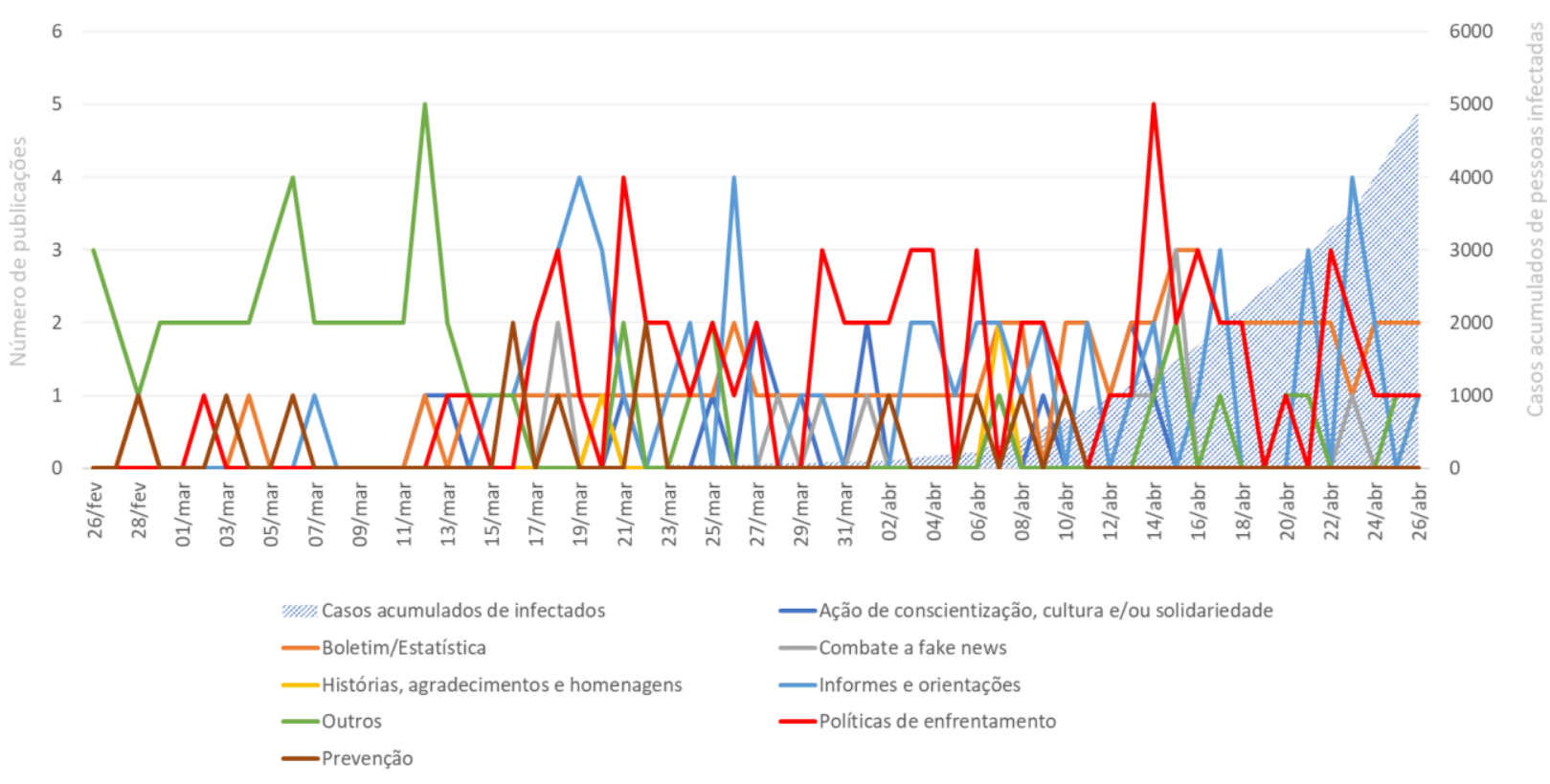

Fonte: Autoria própria (2020).

O governo do Ceará, dentre os três estados analisados, foi o que apresentou uma dinâmica informacional mais contraditória, sobretudo considerando que foi o estado do Nordeste com o maior número de casos confirmados no período analisado, em contrapartida foi o que menos publicou no período, apenas 175 posts. Evidencia-se, de antemão, a categoria 'Outros' (32\%) como a predominante, demonstrando que a grande maioria dos posts foram de conteúdos não relacionados à Covid-19. Em segundo lugar, em consonância com os demais estados, 'Políticas de enfrentamento' (22\%) se destacou, com conteúdos sobre as ações do estado no combate ao novo coronavírus, como aquisição de equipamentos, estruturação de leitos, subsídio à população e decretos. Já na categoria 'Informes e orientações' (19\%), o conteúdo dos posts tratavam de orientações das autoridades de saúde, funcionamento dos órgãos e instituições e canais de comunicação para a população se informar sem precisar sair de casa. Na categoria de 'Ação de conscientização, cultura e/ou solidariedade' (15\%), os posts foram sobre doação de sangue, Festival Cultura Dendicasa (programação da Secretaria de Cultura do estado para entreter a população) e conscientização da população para permanecer em suas casas, evitando assim a rápida disseminação da doença.

As demais categorias apareceram com ainda menos publicações, como é o caso de 'Prevenção' (6\%), com dicas de higienização e, geralmente, estimulando a colaboração conjunta para evitar o contágio. Já na categoria 'Histórias, agradecimentos e homenagens' (3\%), o estado compartilhou histórias de infectados pela Covid-19 que conseguiram se curar da doença e agradecimento à população por ficar em casa, contribuindo para o controle da propagação do vírus. $O$ destaque vai para 'Boletim/Estatística' (2\%), que caracteriza o goveno do Ceará como o menos transparente na divulgação dos números da doença no estado, visto que houve apenas quatro posts enquadrados nessa categoria, sendo dois nos dias 13 e 14 de março, antes da confirmação dos primeiros casos, um no dia 17 de março, quando foram confirmados os primeiros casos de infecção, e o último no dia 18 de março, para informar que a divulgação dos números estava atrasada devido a um problema no sistema de notificação do Ministério da Saúde. Nos dias seguintes, não houve mais boletins para informar à população da disseminação da doença. Em relação ao "Combate a fake News" (1\%), o governo publicou dois posts, um esclarecendo desinformação e outro estimulando a população a se informar pelos canais oficiais. 
Gráfico 10 - Volume de publicações por categoria abordada pelo governo do Ceará

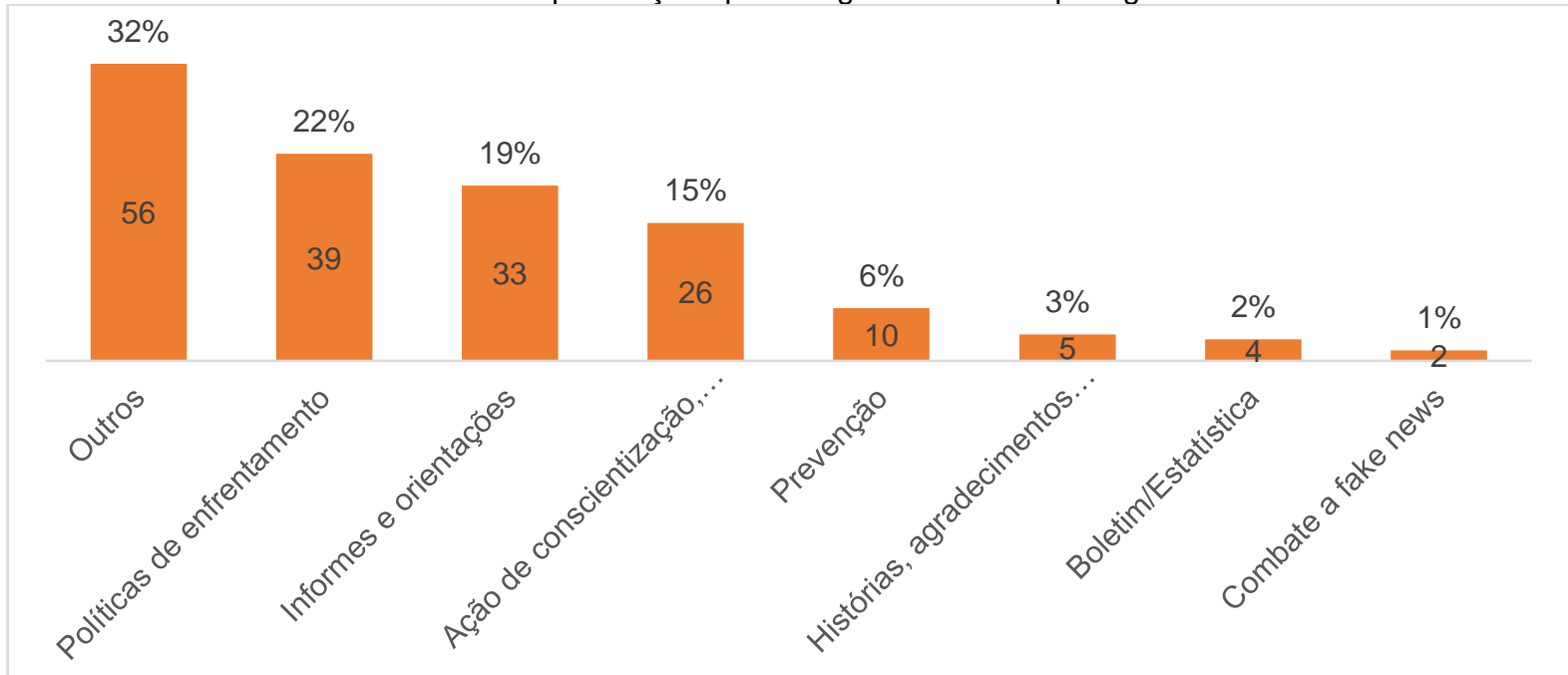

Fonte: Autoria própria (2020).

$\mathrm{Na}$ evolução diária das categorias dos posts do governo do Ceará, ressalta-se que foi o único estado em que os posts não foram diários, havendo alguns dias sem conteúdo postado. Fica evidente a carência da categoria 'Boletim/Estatística', o que interfere diretamente na transparência do governo do estado em relação à divulgação dos números de casos de infectados e mortos pela Covid-19. Embora a categoria 'Outros' seja predominante entre as publicações do governo, observa-se que há um decréscimo a partir da segunda quinzena de março, quando houve a confirmação dos primeiros casos de infectados, em 17 de março de 2020, logo depois essa categoria mantém-se estável. A estabilidade também pode ser observada na categoria 'Ação de conscientização, cultura e/ou solidariedade'. Já após os primeiros casos confirmados, a categoria 'Políticas de enfrentamento' se torna mais proeminente, com dois picos, sendo um em 22 de março e outro em 19 de abril. No dia 22 de março, o governo do Ceará concedeu isenção da conta de água a famílias do padrão de consumo básico da tarifa social e tarifa popular de todo o estado, e no dia 22 de março o governo publicou o decreto $n$ enfrentamento da infecção pelo novo coronavírus.

\section{Gráfico 11 - Evolução diária de publicações por categoria no Ceará}

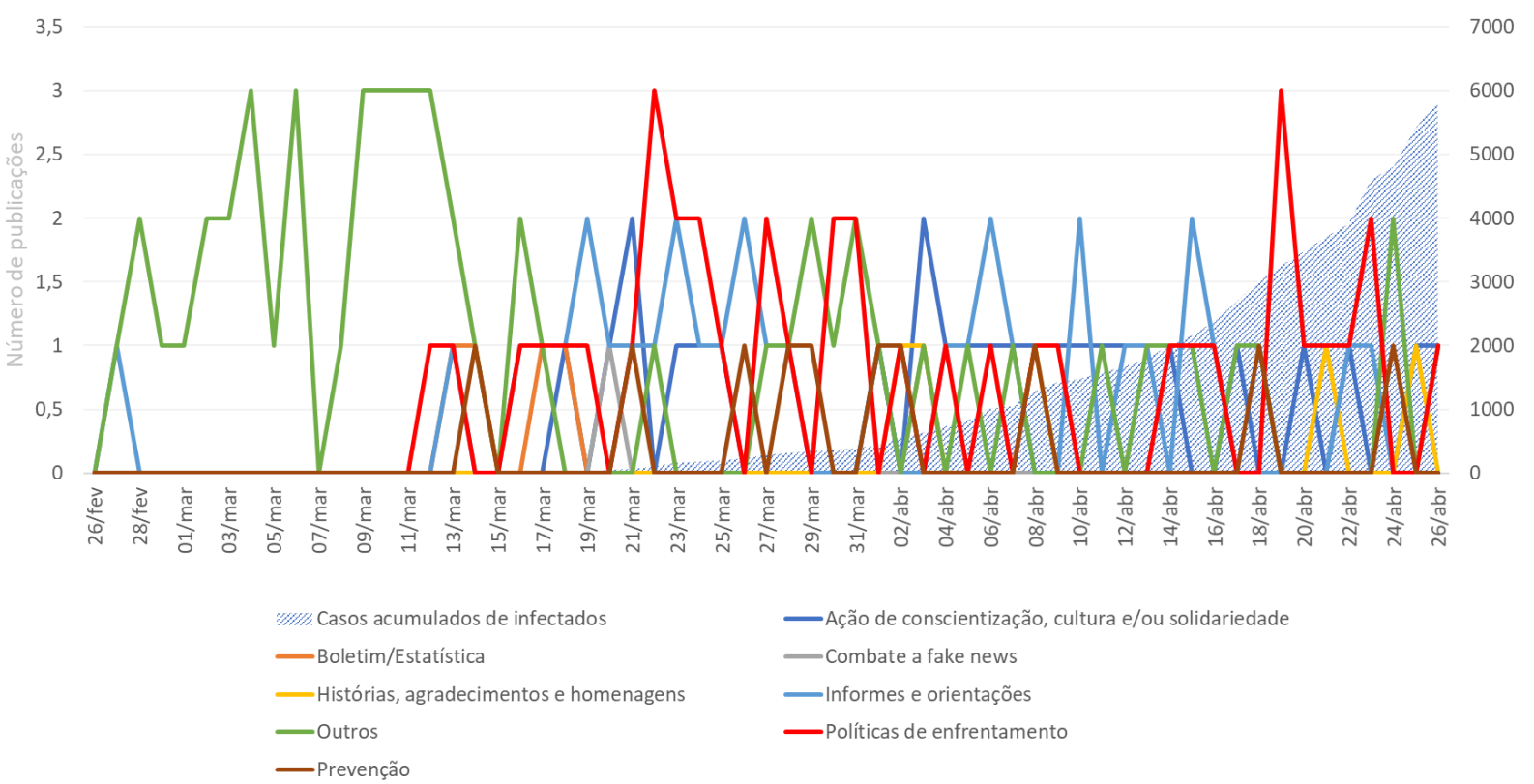

Fonte: Autoria própria (2020). 
A partir das análises realizadas, depreende-se que Pernambuco é o estado com maior transparência na divulgação dos casos de infecção pela Covid-19, mantendo diariamente, desde o início dos casos, as publicações de 'Boletim/Estatística' com os números e evolução da doença no estado. Já o Ceará apresentou deficiência na publicação de posts dessa categoria. Além disso, os três estados preocuparam-se em demonstrar suas ações e medidas formais para minimizar os prejuízos causados pela disseminação do novo coronavírus, seja em termos econômicos, sociais, educacionais e/ou sanitários. Essa inferência pode ser observada no maior número de posts compreendidos na categoria 'Políticas de enfrentamento'. Outra categoria predominante foi 'Informes e orientações', que esteve na terceira posição em todos os estados analisados, com resultados semelhantes, uma vez que o percentual desse tipo de conteúdo em relação ao universo total de posts foi similar nas publicações dos três governos.

Em relação à categoria 'Combate a fake news', Pernambuco demonstrou maior atenção em desfazer boatos e descontruir conteúdos de desinformação. Já na categoria 'Prevenção', Pernambuco e Ceará se dedicaram levemente mais aos conteúdos ligados à higienização. Enquanto isso, a categoria de 'Ação de conscientização, cultura e/ou solidariedade', foi mais publicada, respectivamente, por Ceará, Maranhão e Pernambuco. Por fim, 'Histórias, agradecimentos e homenagens' teve pouca representatividade nos três estados.

\section{Considerações Finais}

A informação é pervasiva. Adentra nas casas, nas comunidades, de diversas maneiras e por diversos canais. Quando as redes sociais digitais surgem, inaugura-se uma nova forma de interação, incorpórea, mas, ainda assim, eminentemente informacional. O apelo à forma, por vezes, se sobrepõe ao conteúdo efetivo do que se deseja transmitir, enquanto prossumidor, ou mero replicador de postagens, de conteúdos autorais, ou terceirizados. Tais redes sociais enredam seus partícipes, sejam efetivos, sejam potenciais, em uma estrutura de uso convidativa, de linguagem acessível e cuja apreensão da atenção se efetiva, portanto, as redes sociais têm uma perspectiva entorpecente e, em certa medida, viciante.

Mas é reducionista afirmar, exclusivamente, que tais meios de informação e comunicação estão somente enredados neste aspecto, eles são também facilitadores da horizontalização das relações interpessoais, e de pessoas com instituições. É neste sentido que se percebe o ingresso quase que obrigatório de empresas públicas e privadas, por meio de perfis verificados, comunicando-se com a população, informando-as, alertando-as, por vezes, entretendo-as. Este estudo revela, conforme ora descrito em seu objetivo específico, que há uma efetivação das práticas informacionais das páginas, ou perfis, dos governos de Ceará, Maranhão e Pernambuco. Diga-se de passagem, o objetivo anterior era congregar toda a Região Nordeste, no entanto, devido ao grande volume de postagens destas páginas, na plataforma Instagram, uma investigação acurada e mais precisa, em termos de artigo, seria inviabilizada. Dois meses de coleta resultaram em mais de mil postagens, uma média de dezesseis postagens por dia, em apenas três estados da Região.

As categorias descobertas no processo de pesquisa nos mostram que tais perfis governamentais preocuparam-se em levar à população suas ações de combate ao Covid-19, bem como trouxeram a realidade possível de apreciação a partir dos dados que revelam o avanço da pandemia. Interessante destacar que cada estado, apesar da constância das categorias, apresentou perfis diferentes. Maranhão apresentou-se como estado preocupado em ter uma constância de postagens que, não necessariamente estavam centradas na pandemia. Já Pernambuco apresenta maior centralidade, o que corrobora com o fato do estado ser, por três vezes, considerado o mais transparente. Já o Ceará mostrou uma constância menor de postagens, mas irreverência ao veicular conteúdos em seu perfil, o que coaduna com a ideia de comunicação deste tipo de ambiente: informações curtas, em tom mais informal. Especialmente Ceará e Maranhão preocuparam-se também com as necessidades culturais de entretenimento de sua população, promovendo eventos desta natureza para distrair a população em distanciamento espacial. Percebemos, neste sentido, a ação efetiva desses estados de tentar chegar à população por meio destes canais à medida em que a pandemia avança.

É certo que os dados aqui coletados não compreendem o fechamento do ciclo, com a queda da curva de crescimento chegando a zero, o que seria de interessante apreciação por pesquisas futuras, mas mostra que os Estados brasileiros, a 
exemplo destes três ora analisados, estão atentos à importância das redes sociais digitais como vias de diálogo com a população.

A pandemia da Covid-19 trouxe reflexões históricas acerca das dinâmicas das relações sociais, políticas e econômicas internacionais, sobretudo, em duas dimensões globais, a primeira do ponto de vista econômico, pautado pela política neoliberal capitalista; e a outra que envolve as questões ambientais e climáticas, que convergem, ambas as dimensões, para o colapso da vida na Terra. Há uma necessidade urgente de se repensar a dinâmica das organizações das sociedades e a forma como esta lida com os insumos e o meio ambiente.

Este momento trouxe à tona algumas questões que se efetivam na mudança das configurações sociais, na forma de interação. Aliando-se à uma outra realidade própria da sociedade em rede, que é o uso das plataformas sociais, o uso do Instagram pelos governos estaduais reforça uma tendência de comunicação que, atinge a todos, em especial aos jovens. Neste sentido, o uso desses canais, com uma linguagem específica e atual, traduz de maneira singular as dinâmicas informacionais utilizadas como estratégia, pelos governos estaduais, para atingir o maior número possível de pessoas, e assim, conseguir informar, auxiliar e proteger seus cidadãos de uma doença letal.

\section{Referências}

AMERICAN LIBRARY ASSOCIATION. Information Literacy Competency Standards for Higher Education. Chicago: ALA, 2000.

AMORIM, Felipe. STF não eximiu governo Bolsonaro de ações contra a covid, diz Fux. Uol, Brasília, 22 jun. 2020. Disponível em: https://noticias.uol.com.br/politica/ultimas-noticias/2020/06/22/stf-nao-eximiu-governo-bolsonaro-de-acoes-contra-a-covid-diz-fux.htm. Acesso em: 24 jun. 2020.

AZEVEDO, Ana Lúcia. No Brasil, coronavírus afeta mais os jovens: faixa de 20 a 49 anos concentra casos, diz estudo. O Globo, Rio de Janeiro, 5 maio 2020. Disponível em: https://oglobo.globo.com/sociedade/coronavirus/no-brasil-coronavirus-afeta-mais-os-jovens-faixa-de20-49-anos-concentra-casos-diz-estudo-24410435. Acesso em: 21 jun. 2020.

BAUMANN, Zygmunt. Modernidade líquida. Rio de Janeiro: Zahar, 2001.

BURKE, Peter. Uma história social do conhecimento - I: de Gutemberg a Diderot. Rio de Janeiro: Zahar, 2003.

BRASIL. [Constituição (1988)]. Constituição da República Federativa do Brasil. Brasília, 1988. Disponível em: http://www.planalto.gov.br/ccivil 03/Constituicao/Constituicao.htm. Acesso em: 10 ago. 2020.

BRASIL. Câmara dos Deputados; BRASIL. Senado Federal. Redes Sociais, Notícias Falsas e Privacidade de Dados na Internet: Pesquisa DataSenado. Brasilia: DataSenado, nov. 2019. Disponível em:

https://www12.senado.leg.br/institucional/datasenado/arquivos/mais-de-80-dos-brasileiros-acreditam-que-redes-sociais-influenciam-muito-aopiniao-das-pessoas. Acesso em: 21 jun. 2020.

CASTELLS, Manuel. A sociedade em Rede. 20. ed. São Paulo: Paz e Terra, 2019.

CASTELLS, Manuel. O poder da comunicação. Rio de Janeiro: Paz e Terra, 2015.

CONGRESSO EM FOCO. "Gripezinha" e "histeria": cinco vezes em que Bolsonaro minimizou o coronavírus. 1 abr. 2020. Disponível em: https://congressoemfoco.uol.com.br/governo/gripezinha-e-histeria-cinco-vezes-em-que-bolsonaro-minimizou-o-coronavirus/. Acesso em: 24 jun. 2020.

CRESWELL, John W.; CLARK, Vicki L. Pesquisa de métodos mistos. Porto Alegre: Penso, 2007.

D'ANCONDA, Matthew. Pós-verdade: a nova guerra contra os fatos em tempos de fake News. Barueri: Faro Editorial, 2018.

DUDZIAK, Elizabeth Adriana. Information Literacy: princípios, filosofia e prática. Ciência da Informação, Brasília, v. 32, n. 1, p. 23-35, jan./abr. 2003. DOI: http://dx.doi.org/10.1590/S0100-19652003000100003. Disponível em: https://www.scielo.br/scielo.php?pid=S0100$19652003000100003 \% 20 \&$ script=sci arttext. Acesso em: 10 ago. 2020.

FERNANDES, Talita. Bolsonaro defende uso de hidroxicloroquina ainda em fase inicial da Covid-19. Folha de São Paulo, São Paulo, 8 abr. 2020. Disponível em: https://www1.folha.uol.com.br/equilibrioesaude/2020/04/bolsonaro-defende-uso-de-hidroxicloroquina-ainda-em-faseinicial-da-covid-19.shtml. Acesso em: 24 jun. 2020.

FRAGÃO, Luisa. Dia do Nordestino: falas preconceituosas marcam o primeiro ano do governo Bolsonaro. Revista Forum, Santos, 8 out. 2019. Disponível em: https://revistaforum.com.br/politica/bolsonaro/dia-do-nordestino-falas-preconceituosas-marcam-o-primeiro-ano-dogoverno-bolsonaro/. Acesso em: 21 jun. 2020.

GITLIN, Todd. Mídias sem limites: como a torrente de imagens e sons domina nossas vidas. Rio de Janeiro: Civilização Brasileira, 2003.

HOLANDA, Marianna. Fala de Bolsonaro sobre Nordeste é 'antipatriótica', diz general; Dino rebate presidente: 'postura beligerante'. Estadão, São Paulo, 20 jul. 2019. Disponível em: https://politica.estadao.com.br/blogs/coluna-do-estadao/fala-de-bolsonaro-sobre-nordestee-antipatriotica-e-incoerente-diz-general/. Acesso em: 21 jun. 2020. 
As Dinâmicas Informacionais do conteúdo publicado pelos Governos do Ceará, do Maranhão e de Pernambuco e as relações com as estatísticas por coronavírus

KER, João; CAMBRICOLI, Fabiana; VARGAS, Mateus. Defendida por Bolsonaro, cloroquina aumenta risco de morte em pacientes, diz estudo. Estadão, São Paulo, 22 maio 2020. Disponível em: https://saude.estadao.com.br/noticias/geral,defendida-por-bolsonaro-cloroquinaaumenta-risco-de-morte-em-pacientes-diz-estudo,70003311202. Acesso em: 24 jun. 2020.

LAU, José. Diretrizes sobre o desenvolvimento de habilidades em informação para aprendizagem permanente. Bauru: Unesp, 2008.

MAIA, Samantha. Consórcio Nordeste: entenda o que é a iniciativa. Instituto para Reforma das Relações entre Estado e Empresa, [S.I.], 2019. Disponível em: https://iree.org.br/consorcio-nordeste-entenda-o-que-e-a-iniciatival. Acesso em: 21 jun. 2020.

MARTELETO, Regina M. Redes sociais, mediação e apropriação de informação: situando campo, objetos e conceitos na pesquisa em ciência da informação. Tendências da Pesquisa Brasileira em Ciência da Informação, Brasília, v.3, n.1, p.27-46, jan./dez., 2010. Disponível em: https://www.brapci.inf.br/index.php/article/download/13080. Acesso em: 1 abr. 2020.

MARTELETO, Regina M. Análise de redes sociais: aplicação nos estudos de transferência da informação. Ciência da Informação, Londrina, v. 30, n. 1, p. 71-81, jan./abr. 2001. Disponível em: http://revista.ibict.br/ciinf/article/view/940/977. Acesso em: 14 jun. 2020.2020.

MATOS, Haroldo José de. A próxima pandemia: estamos preparados? Revista Pan-Amazônica de Saúde, Ananindeua, v. 9, n. 3, set., 2018. Disponível em: http://scielo.iec.gov.br/scielo.php?script=sci arttext\&pid=S2176-62232018000300009. Acesso em: 24 maio 2020.

MAZUI, Guilherme. Após Teich alertar sobre risco da cloroquina, Bolsonaro defende o remédio e pede ministros 'afinados' com ele. G1, Política, Brasília, 13 maio 2020. Disponível em: https://g1.globo.com/politica/noticia/2020/05/13/apos-teich-fazer-alerta-sobre-cloroquinabolsonaro-defende-o-medicamento-e-pede-ministros-alinhados-com-ele.ghtml. Acesso em: 24 junho 2020.

MCLUHAN, Marshall. The Gutenberg Galaxy: the making of typographic man. Toronto: University of Toronto, 1962.

MIRANDA, Ary Carvalho de; BARCELLOS, Christovam; MOREIRA, Josino Costa; MONKEN, Maurício (Org.). Território, ambiente e saúde. Rio de Janeiro: Editora Fiocruz, 2008.

NOBRE, Eliani Alves; PÔRTO, Isabel Maria Salustiano Arruda. Democracia, Transparência e participação popular, analisados sob o prisma constitucional. Revista do Ministério Público do Ceará, Fortaleza, v. 1, 2012. Disponível em: http://tmp.mpce.mp.br/esmp/publicacoes/edi001 2012/artigos/10 Eliani.Alves.Nobre.pdf. Acesso em: 5 maio 2020.

O GLOBO. Bolsonaro volta a criticar isolamento social contra o coronavírus. O Globo, 16 maio 2020. Disponível em: https://oglobo.globo.com/brasil/bolsonaro-volta-criticar-isolamento-social-contra-coronavirus-24430964. Acesso em: 24 maio 2020.

ORGANIZAÇÃO DAS NAÇÕES UNIDAS. Declaração Universal dos Direitos Humanos. Rio de Janeiro: ONU Brasil, ago. 2009. Disponível em: https://nacoesunidas.org/wp-content/uploads/2018/10/DUDH.pdf. Acesso em: 05 maio 2020.

PHILLIPS, Jeff. The Genesis of Intoxin. fev. 2002. Disponível em: http://synthaissance.blogspot.com.br/2006/07/synth-archive19-genesisof-infotoxin.html. Acesso em: 04 mar. 2013.

PITOMBO, João Pedro. Anos após decapitações, Pedrinhas tem estrutura melhor, mas continua lotado. Folha de São Paulo, São Paulo, 19 ago. 2019. Disponível em: https://www1.folha.uol.com.br/cotidiano/2019/08/anos-apos-decapitacoes-pedrinhas-tem-estrutura-melhormas-continua-lotado.shtml. Acesso em: 24 jun. 2020.

REIS JÚNIOR, Casemiro dos. Capitalismo e a Covid-19. In: CASTRO, Daniel; SAL SENO, Danillo; POCHMANN, Márcio (Org.). Capitalismo e a Covid-19: um debate urgente. São Paulo: [s. n.], 2020. p. 164-173. Disponível em: http://abet-trabalho.org.br/wpcontent/uploads/2020/05/LIVRO.CapitalismoxCovid19.pdf. Acesso em: 24 jun. 2020.

SAMPAIO, Denise Braga. Mediação bibliotecária no desenvolvimento de competências em informação para o uso do portal de periódicos da Capes. 2016. Dissertação (Mestrado em Ciência da Informação) - Programa de Pós-Graduação em Ciência da Informação, Universidade Federal de Pernambuco, Recife, 2016. Disponível em:

https://repositorio.ufpe.br/bitstream/123456789/23533/1/Disserta\%C3\%A7\%C3\%A30\%20VF\%20-\%20Denise\%20Sampaio.pdf. Acesso em: 02 maio 2020.

SAMPAIO, Denise Braga; LIMA, Izabel França de; ROSA, Maria Nilza Barbosa; OLIVEIRA, Bernardina Maria Juvenal Freire de. Redes Sociais como Lugares Enviesados de Memória: um discurso coletivo da paralização dos caminhoneiros de 2018. Informação\&Informação, Londrina, v. 25, n. 1, p. 66-91, jan./mar. 2020. DOI: http://dx.doi.org/10.5433/1981-8920.2020v25n1p66 Disponível em: http://www.uel.br/revistas/uel/index.php/informacao/article/view/35870. Acesso em: 22 jun. 2020.

SANTOS, Boaventura de Sousa. A cruel pedagogia do vírus. Coimbra: Almedina, 2020. Disponível em: https://www.cpalsocial.org/documentos/927.pdf. Acesso em: 24 jun. 2020.

SANTOS, Helena. Complexidade e informacionalismo: as contribuições de Edgar Morin e Manuel Castells. In: PASSARELLI, Brasilina; SILVA, Armando Malheiros da; RAMOS, Fernando (Org.). e-Infocomunicação: estratégias e aplicações. São Paulo: Editora SENAC, 2014. p. 25-47.

SANTOS, Íris Almeida dos; NASCIMENTO, Wanderson Flor do. As medidas de quarentena humana na saúde pública: aspectos bioéticos. Revista Bioethikos, Centro Universitário São Camilo, v. 8. n. 2, p. 174-185, 2014. Disponível em: https://saocamilosp.br/assets/artigo/bioethikos/155563/A05.pdf. Acesso em: 24 jun. 2020.

SANTOS, Milton. Por uma outra globalização: do pensamento único à consciência universal. 6. ed. Rio de Janeiro: Record, 2001.

SCHAFF, Adam. A sociedade informática: as consequências sociais da segunda revolução industrial. São Paulo: Brasiliense, 1995.

SÊGA, Christina Pedrazza. Sociedade e interação: um estudo das diferentes formas de interagir. Brasília: UnB, 2011.

SILVA, Antônio Braz de Oliveira; MATHEUS, Renato Fabiano. Análise de redes sociais como metodologia de apoio para a discussão da interdisciplinaridade na ciência da informação. Ciência da Informação, Brasília, v. 35, n. 1, p. 72-93, jan./abr. 2006. Disponível em: https://www.scielo.br/pdf/ci/v35n1/v35n1a09.pdf. Acesso em: 14 jun. 2020. 
SOUZA, José Neivaldo de. Covid-19 e capitalismo: uma visão. In: CASTRO, Daniel; SAL SENO, Danillo; POCHMANN, Márcio (Org.). Capitalismo e a Covid-19: um debate urgente. São Paulo: [s.n.], 2020. p.11-18. Disponível em: http://abet-trabalho.org.br/wpcontent/uploads/2020/05/LIVRO.CapitalismoxCovid19.pdf. Acesso em: 24 jun. 2020.

TEIXEIRA, Matheus. Estados e municípios não precisam seguir listas de atividades essenciais de Bolsonaro; entenda. Folha de São Paulo, São Paulo, 12 maio 2020. Disponível em: https://www1.folha.uol.com.br/cotidiano/2020/05/estados-e-municipios-nao-precisamseguir-listas-de-atividades-essenciais-de-bolsonaro-entenda.shtml?origin=folha. Acesso em: 24 jun. 2020.

TOFFLER, Alvim. A terceira onda. 8. ed. Rio de Janeiro: Record, 1980.

TOFFLER, Alvim. Powershift: as mudanças do poder. 8. ed. Rio de Janeiro: Record, 1990.

TOSTES, Anjuli; MELO FILHO, Hugo. Quarentena: Reflexões sobre a pandemia e depois. Bauru: Canal 6 Editora, 2020.

TRIVIÑOS, Augusto Nibaldo Silva. Introdução à pesquisa em ciências sociais: a pesquisa qualitativa em educação. São Paulo: Atlas, 1987.

UJVARI, Stefan Cunha. Pandemias: a humanidade em risco. São Paulo: Contexto, 2011.

UOL. Bolsonaro diz no Twitter que isolamento total por coronavírus é 'tirania'. Uol, São Paulo, 15 maio 2020. Disponível em: https://noticias.uol.com.br/politica/ultimas-noticias/2020/05/16/bolsonaro-diz-no-twitter-que-isolamento-total-por-coronavirus-e-tirania.htm. Acesso em: 24 jun. 2020.

VALFRÉ, Vinícius. Bolsonaro volta a criticar isolamento social: 'Não dá para continuar assim'. Uol, São Paulo, 25 maio 2020 . Disponível em: https://noticias.uol.com.br/ultimas-noticias/agencia-estado/2020/05/26/bolsonaro-volta-a-criticar-isolamento-social-nao-da-para-continuarassim.htm. Acesso em: 24 jun. 2020.

ZUBOFF, Schoshana. Big other: capitalismo de vigilância e perspectivas para uma civilização de informação. In: BRUNO, Fernanda; CARDOSO, Bruno; KANASHIRO, Marta; GUILHON, Luciana; MELGAÇO, Lucas (Org.). Tecnopolítica da vigilância: perspectivas à margem. São Paulo: Boitempo, 2018.

\section{UNIVERSIDADE
FEDERAL DO CARIRI}

Centro de Ciências Sociais Aplicadas Mestrado Profissional em Biblioteconomia

Este periódico é uma publicação do Programa de Pós-Graduação em Biblioteconomia da Universidade Federal do Cariri em formato digital e periodicidade quadrimestral. 